\title{
Geo-Economic Explanation of Iran's Relations with Kazakhstan
}

\section{ART ICLE INF O}

\section{Article Type}

Original Research

\section{Authors}

Rabiee H.* PhD,

Abbasi Pour Nezam Abad R. ${ }^{1} M A$

Amir Ahmadian B. ${ }^{2} P h D$

Abdi A. ${ }^{3} P h D$
How to cite this article

Rabiee H, Abbasi Pour Nezam

Abad R, Amir Ahmadian B, Abdi

A. Geo-Economic Explanation of Iran's Relations with Kazakhstan. Geographical Researches Quarterly Journal.2018;33(2):22-39.

\section{A B S T R A C T}

Introduction \& Background The collapse of the Soviet Union and the formation of new republics have further enhanced the geo-economic position of Iran in the region and the world. The Republic of Kazakhstan is enclosed in the land, and it needs short and reliable communication routes to open water for supplying diverse demands and supplying its oil and gas to world markets. The geostrategic position of Iran in the heart of the Middle East region is a valuable but po-tential reality that can create diverse geopolitical and geopolitical capacities and, as a result, increase national income, development and even security for the country. But the causes and factors such as the vacuum of power resulting from the collapse of the Soviet Union, regional geopolitical rivalry, the important position of Iran near the intersection of Asia and Europe, the existence of large reserves of energy in the region and the desire of Central Asian countries to the presence of foreign powers, The presence of major powers in Central Asia has created serious barriers to Iran's more effective presence in the region. Aims: This article seeks to answer the question of what role Kazakhstan can play in the presence of Iran in Central Asia.

Methodology This applied research has been done by descriptive-analytical method and its data have been compiled by library method. By providing other statistics and other documents, Kazakhstan's geo-Kazakhstani weight in Central Asia and the role that can be played in facilitating penetration and presence Iran has estimated in the region.

Conclusion The result of the research shows that Kazakhstan plays a key role in geo-economic relations. Islamic Republic of Iran has Central Asia and can cre-ate the potential and potential for Iran to enter Central Asia.

Keywords Geopolitics; Geo-economics; Central Asia; Iran and Kazakhstan
*Department of Political Geography, Faculty of Geographical Sciences, Kharazmi University, Tehran, Iran

${ }^{1}$ Department of Political Geography, Faculty of Geographical Sciences, Kharazmi University, Tehran, Iran

${ }^{2}$ Department of Political Geog-raphy, Faculty of Geographical, Tehran University, Tehran, Iran ${ }^{3}$ Department of Political Geography, Faculty of Geographical Sciences, Kharazmi University, Tehran, Iran

\section{*Correspondence}

Address: Department of Political Geog-raphy, Faculty of Geographical Sciences, Kharazmi University, Tehran, Iran

Phone: -

Fax: -

hosseinrabiei@hotmail.com

\section{Article History}

Received: May 25, 2018

Accepted: August 28, 2018

ePublished: September 17, 2018

\section{I T A T I O N L I N K S}

[Ahmadi Lafouraki \& Mirrazavi; 2004] Directory of Caspian ...; [Akbarian; 2003] Investigating Iran's ...; [Amirahmadian; 2018] The Initiative of one ...; [Amirahmadian; 2018] The Challenges of Iran Presence ...; [Baru; 2012] Geo-economics and ...; [Blackwill \& Harris; 2016] War by other ...; [Caucasuss Studies Institute; 2011] Central Asia and the Caucasus ...; [Dadandish; 2007] Geopolitical discourse in ...; [Economic Site of the Ministry of Foreign Affairs; 2018] Public information of ...; [Efegil \& Stone; 2001] Iran's interests in ...; [EIA; 2016] Iran energy data ...; [EIA; 2017] Kazakhstan energy ...; [Etaat \& Nosrati; 2009] Iran and energy ...; [Ezzati; 2001] Geopolitics in the ...; [Ezzati; 2008] The geoeconomy of ...; [Fao; 2015] Country indicators ...; [Fars News Agency; 2011] Larijani meeting with ...; [Valigholizadeh; 2015] Spatial-geoeconomic ...; [Golshani \& Sohrabi; 2012] The role of Iran's geopolitics ...; [Hafez Nia; 2006] Geopolitical principles ...; [Hashemi; 2004] Political history ...; [Johnston, Teilor \& Wats; 2004] Global geography ...; [Kaiser \& Pulsipher; 2007] A review of the oil and ...; [Kamp \& Harcavi; 2007] Strategic geography ...; [Karami \& Azizi; 2013] China's security relations with ...; [Kasenov \& Sanjabi; 1996] Kazakhstan's foreign ...; [Kennedy; 1989] The rise and fall of the ...; [Koolaee; 1997] Politics and government ...; [Koolaee; 2009] Explanation of the Islamic ...; [Koolaee \& Ebrahimi; 2012] Explanation of the Islamic ...; [Koolaee \& Moaddab; 2009] Iran's role and importance ...; [Koushki \& Hosseini; 2017] Prospect of Islanic Republic ...; [Lotfian; 2011] Kazakhstan: Political ...; [Luttwak; 1990] From geopolitics ...; [Marat; 2008] The republic of Kazakhstan ...; [Martin \& Miguel; 2010] Geo-economics in Central ...; [Ministry of Foreign Affairs; 2008] Kazakhstan ...; [Mirhosseini; 2010] Introduction to ...; [Mohammadi \& Motaghi; 2006] Doctrine on constructive ...; [Mottaghi \& Hemmatkhah; 2008] The position of Iran in ...; [Nasiri; 2008] Globalregional ...; [Oliker; 2007] Kazakhstan's security ...; [Paramonov \& Strokov; 2007] Structural interdependence ...; [Peachey; 2011] Petroleum investment ...; [Pishgahi Fard \& Joneidi; 2010] The nature of Russia's ...; [Ramazani; 2009] Understanding Iran's ...; [Rasa News Agency; 2014] Retrieved from ...; [Sarie'olghalam; 2017] International system ...; [Shahbi \& Sheikholeslami; 2011] Echo and Development ...; [Shouri; 2016] Promoting Iran-Russia ...; [Solberg Søilen; 2012] Geoeconomics ...; [Tehran Chamberog Commerce Industries Minies and Agriculture; 2015] Basic information ...; [The World Factbook; 2016] Retrieved from ...; [Trade Promotion Organization of Iran; 2015] Report on trade between ...; [Yuldasheva; 2008] Geopolitics of Central ...; [Zabortsevas; 2010] Kazakhstan's bilateral ... ; [Zardykhan; 2002] Kazakhstan and Central ... 
Rabiee H. PhD

Abbasipour Nezam Abad R. MA Amir Ahmadian B. PhD

Abdi A. PhD

hosseinrabiei@hotmail.com

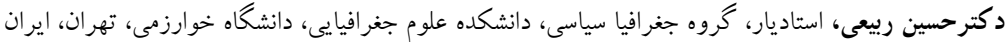

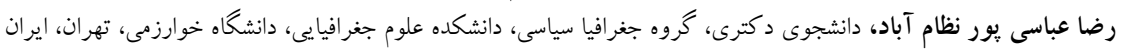

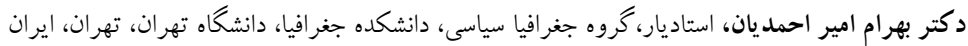

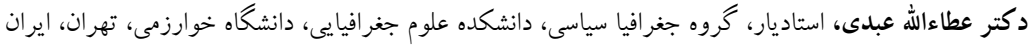

\section{تبيين زئواكونوميك مناسبات ايران با قزاقستان}

يذيرش نهايى:وV/\&/9

دريافت مقاله: MV/T/F

DOI: $10.29252 /$ geores.33.2.22

مقدمه: فروياشى شوروى و شكل گيرى جمهورىهاى جديد، موقعيت زئواكونوميكى ايران را در منطقه وجهان، بيشازييش

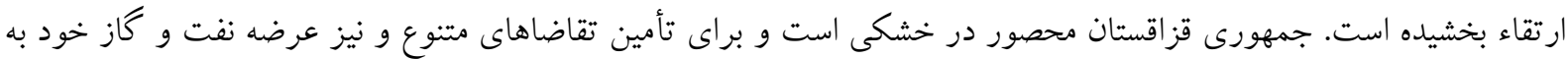

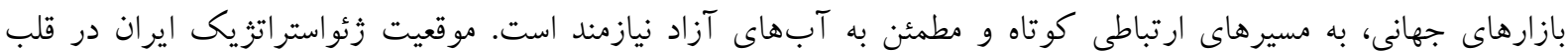

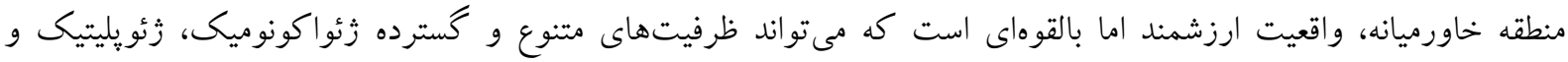

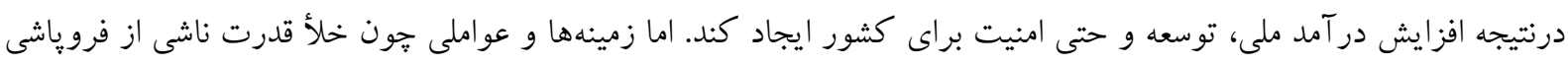

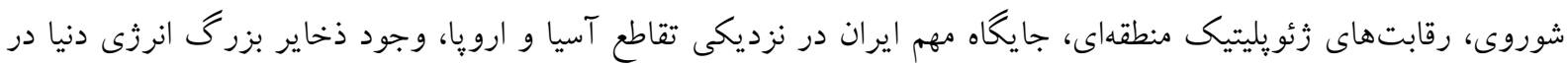

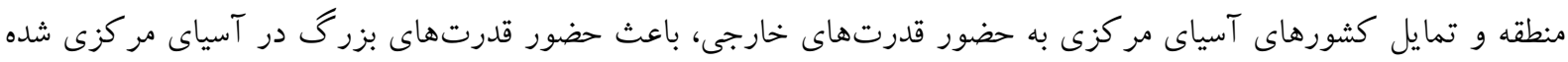

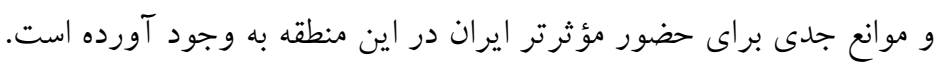

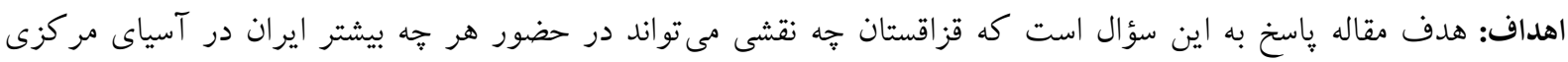
داشته باشد.

مواد و روشها: اين يزوهش ازنظر هدف كاربردى و ازنظر روش، توصيفى-تحليلى است. دادهاى موردنياز آن به روش

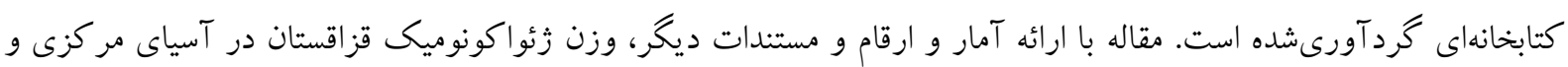
نقشى كه مىتواند در زمينه تسهيل نفوذ و حضور ايران در منطقه داشته باشد را بر آورد كرده است.

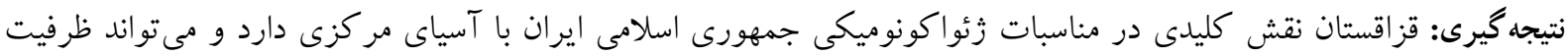

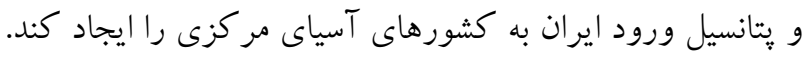
واز كان كليدى: زئويليتيك، زئواكونوميك، آسياى مر كزى، ايران و قزاقستان

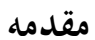

رقابت و كنش كشورها و گروهها بر سر منابع كمياب يا ناياب زمين از زمان ييدايش نخستين اجتماعات بشرى در جريان

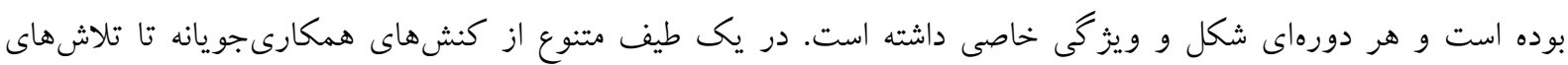

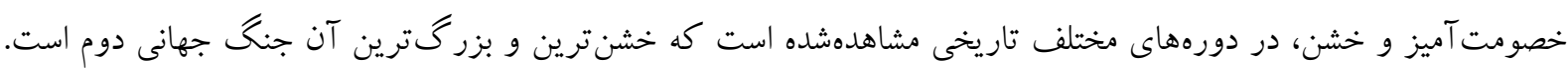


ادعا مىشود كه در دهه هاى اخير تلاشهاى خشونت آميز جاى خود را به رقابتهاى سياسى و دييلماتيك داده است و در زمان

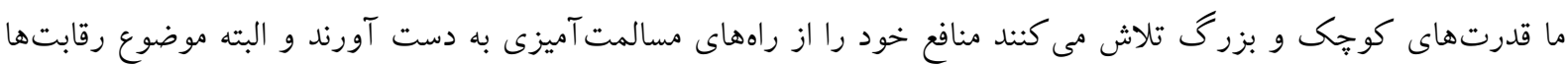

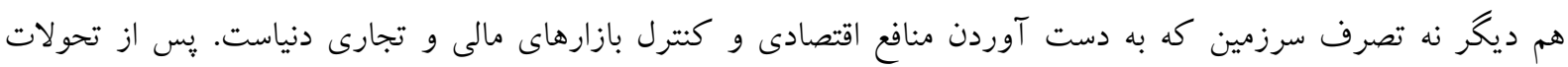

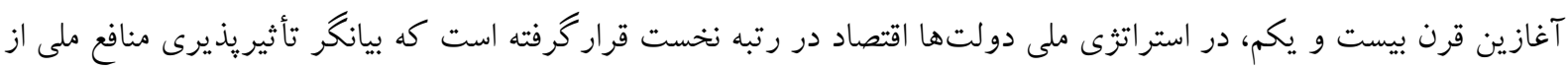

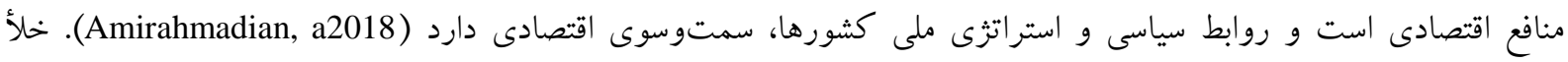
قدرت به وجود آمده در آسياى مركزى پيس از فروياشى اتحاد شوروى موجب ورود ساير قدرتها و درنتيجه شكل كيرى يك رونى

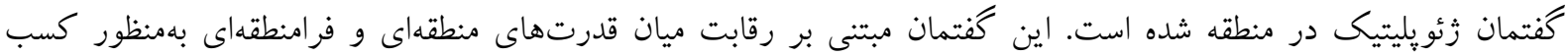

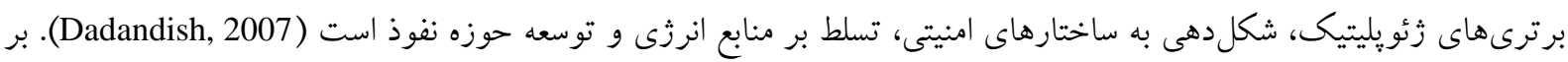

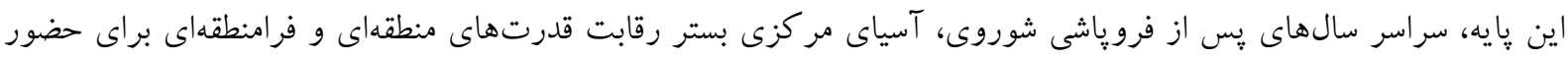

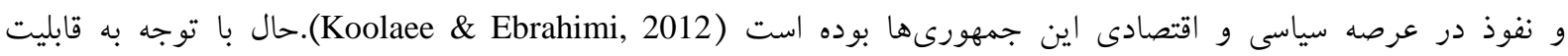

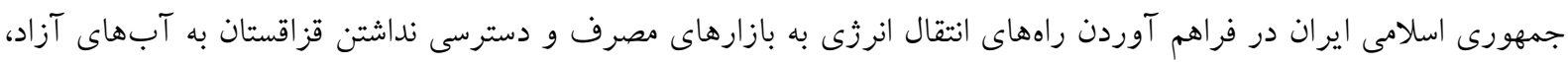

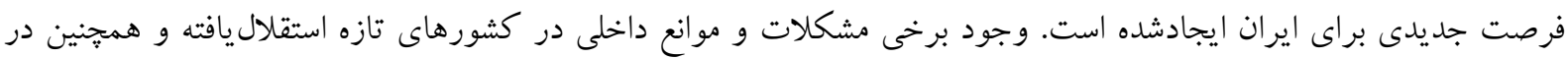

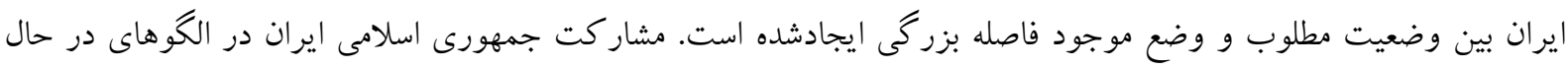

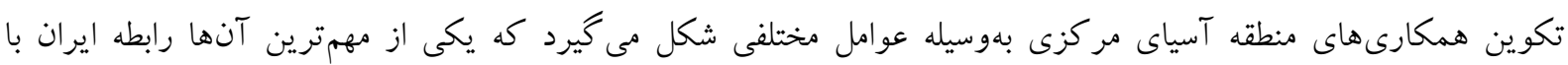

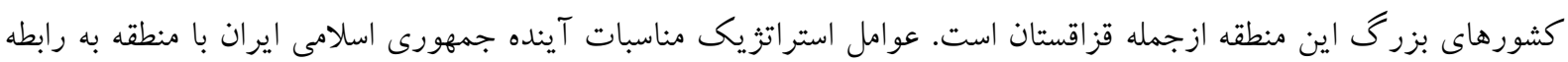

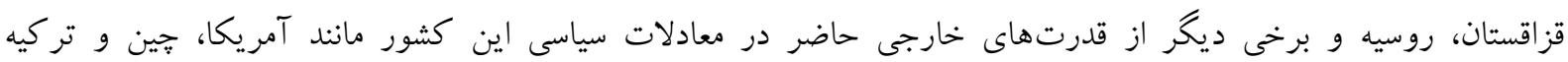

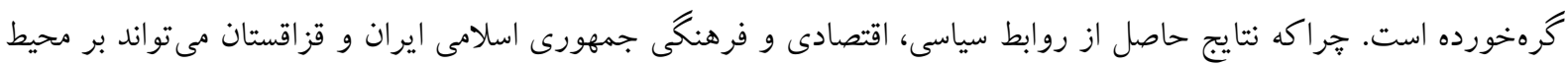

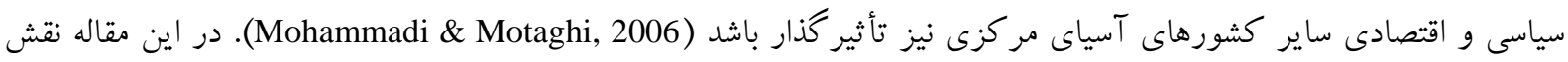

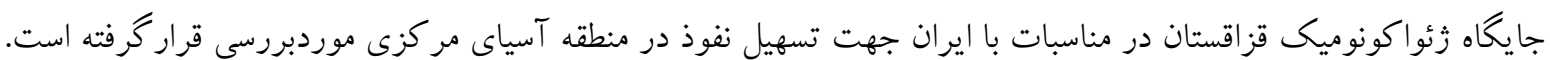

\section{روش يزووهش}

يزوهش حاضر ازنظر ماهيت، كاربردى و ازلحاظ روش، توصيفى - تحليلى است. دادها و اطلاعات موردنياز نيز به روش

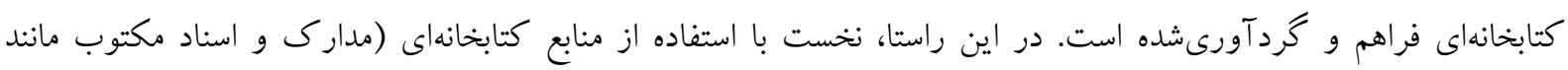

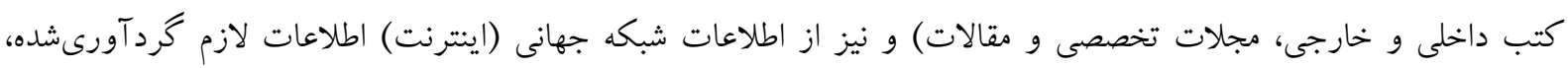
سبّ با استفاده از روش توصيفى - تحليلى، اقدام به تحليل و بررسى دادهها شده است.

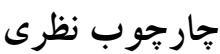

اصطلاح زئواكونوميك امروزه بسيار استفاده مىشود، اما به كفته لوتواك، زئواكونوميك با هر تعريف و برداشتى، همواره

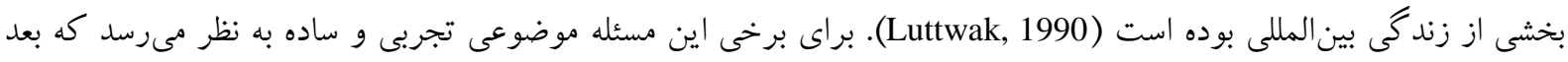

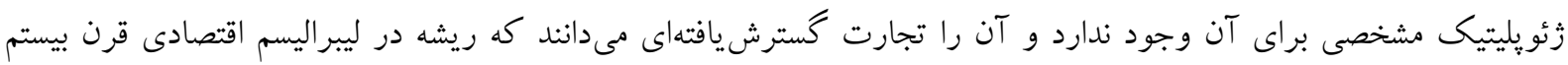

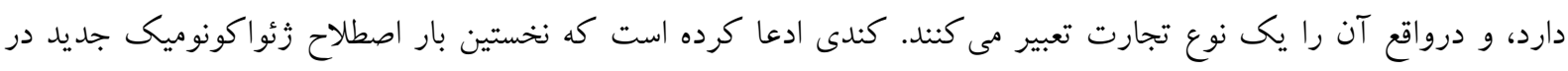

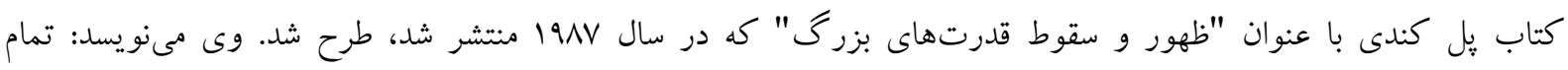

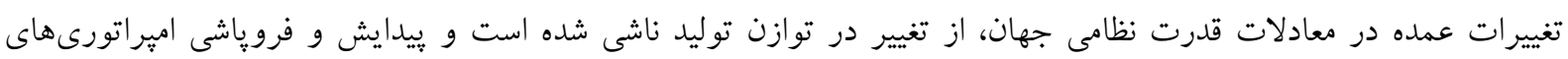

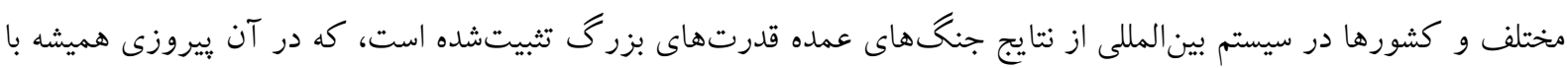


بزرگترين منابع مادى رفته است (Kennedy, 1989). سانجايا مىنويسد: زئواكونوميك ممكن است به دو روش متفاوت

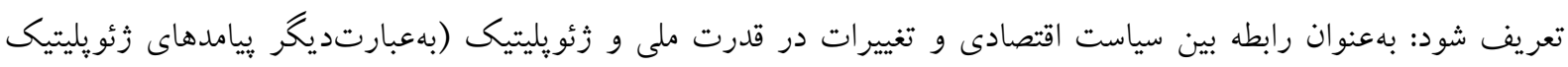

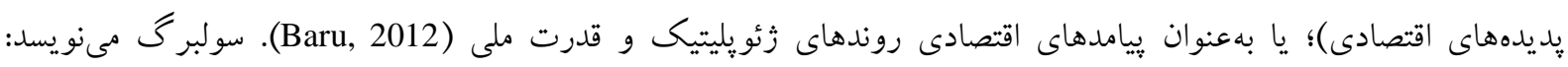

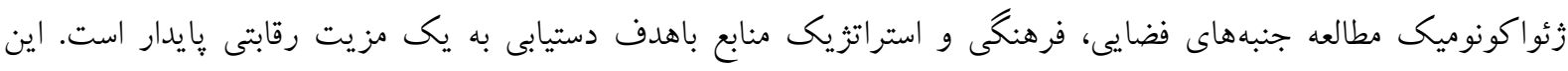

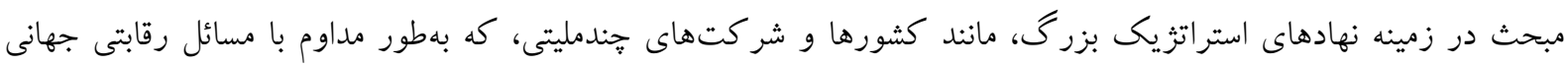

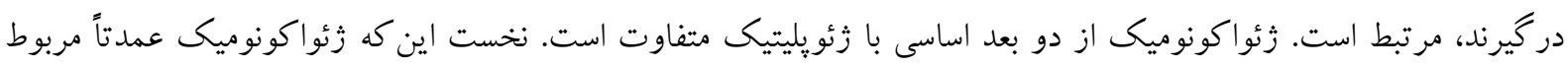

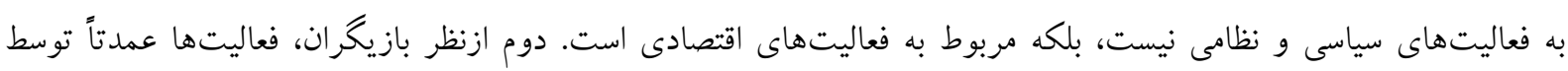

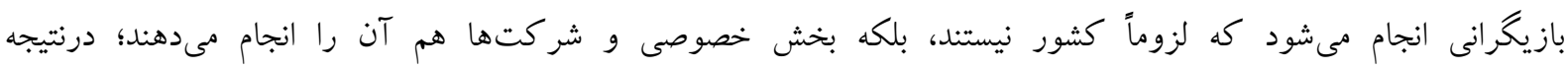

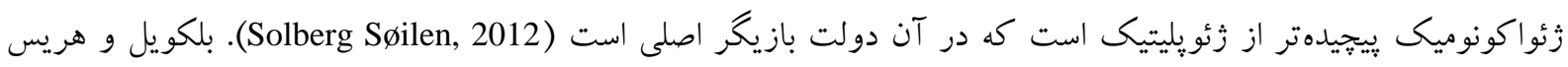

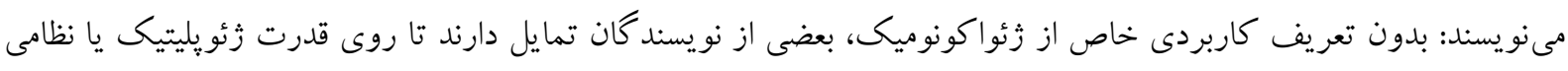

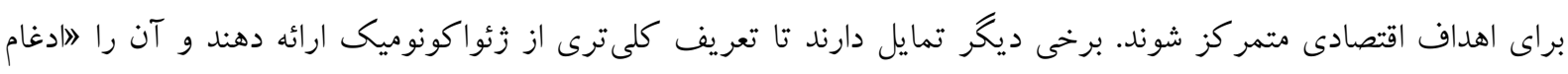

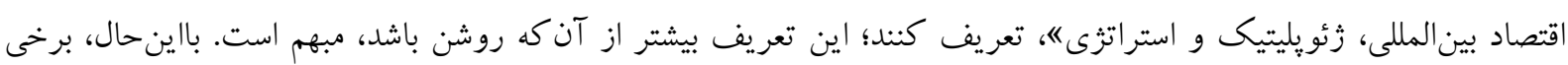

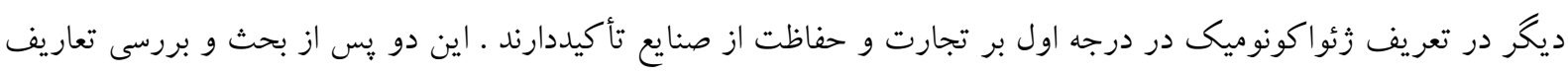

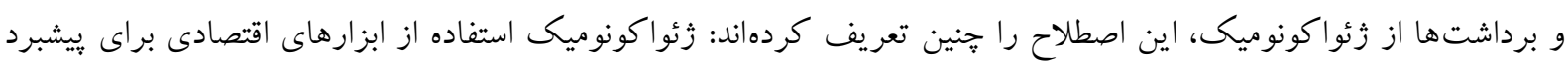

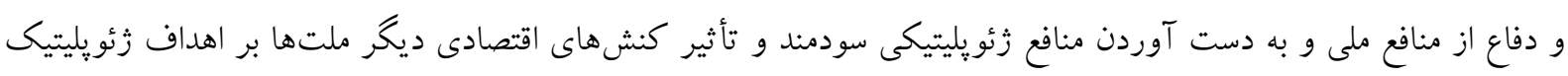

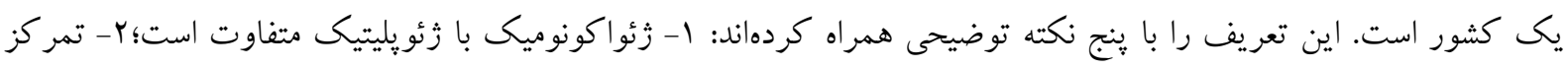

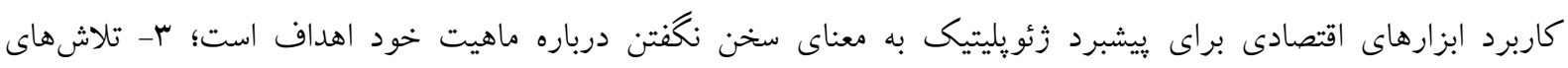
زئواكونوميك در قدرتنمايى مىتواند اشكال مختلفى داشته باشد و درست مثل اينكه همه كشورها

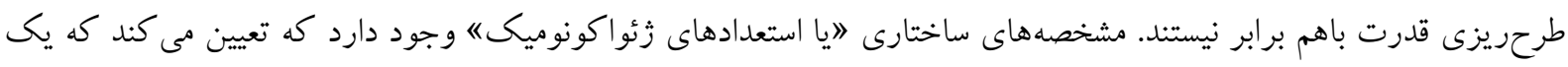

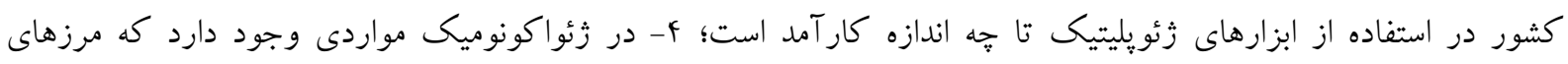

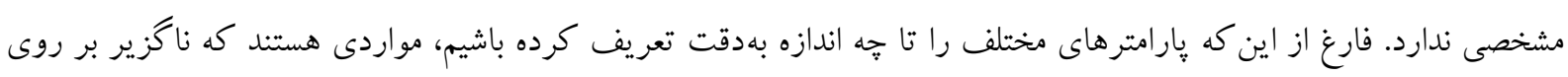

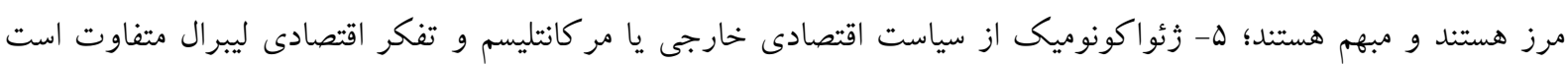

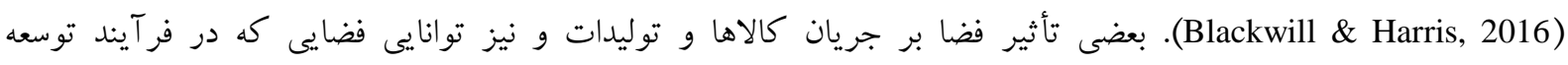

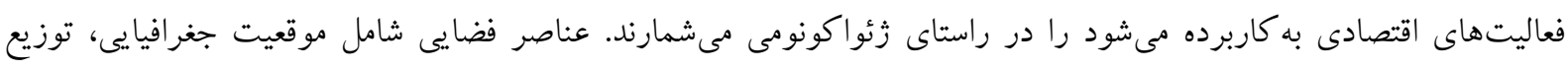

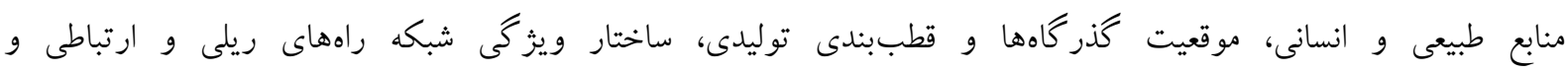

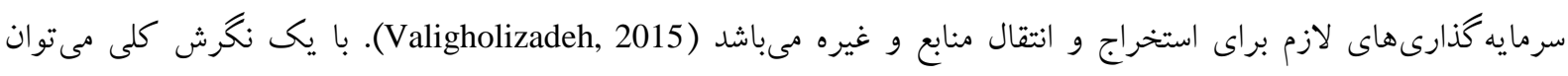

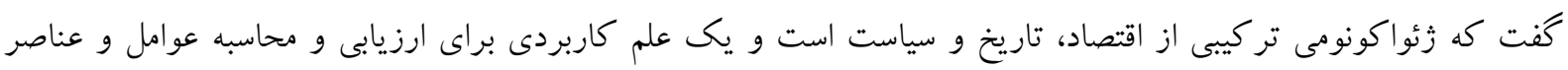

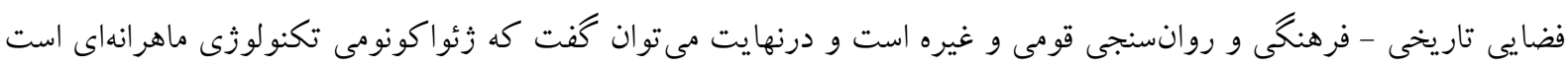

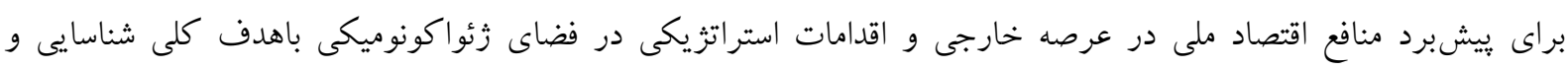

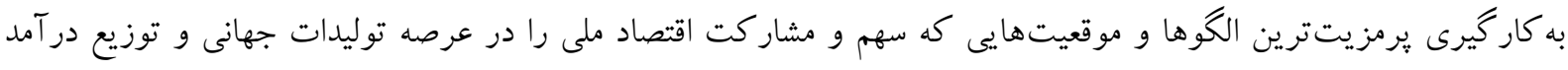

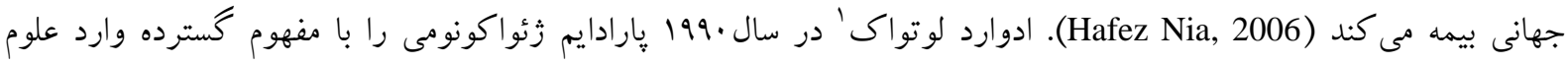

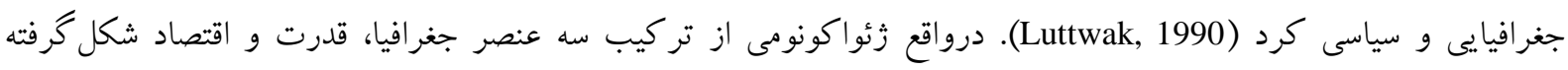

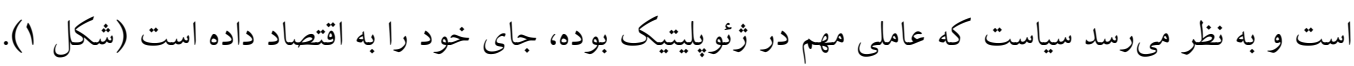




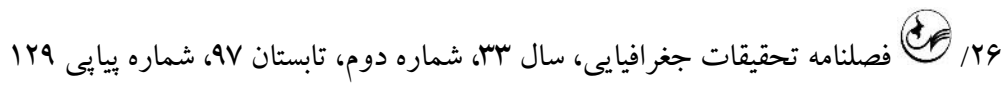

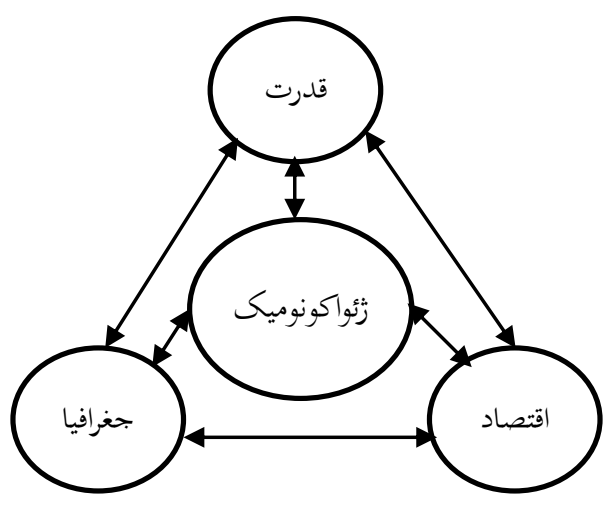

شكل 1- مدل مفهومى زئواكونومى

فروياشى اتحاد جماهير شوروى در سال 1991 و اعلام استقلال ها جمهورى آن با مطرحشدن استراتزى جديد

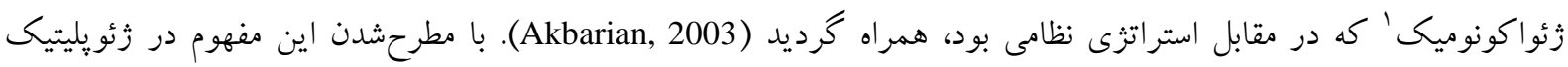

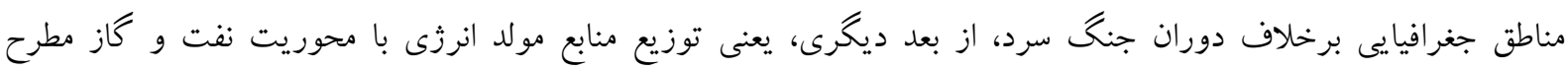

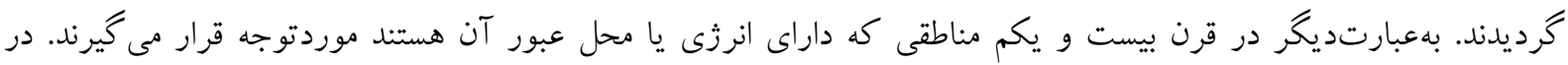

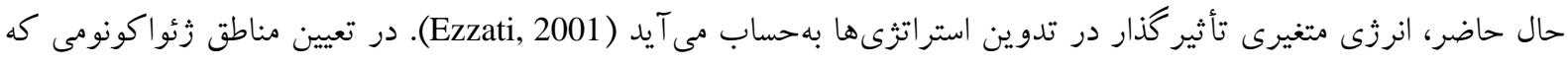

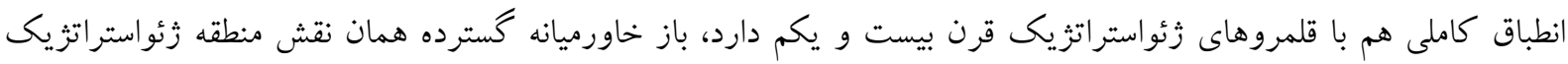

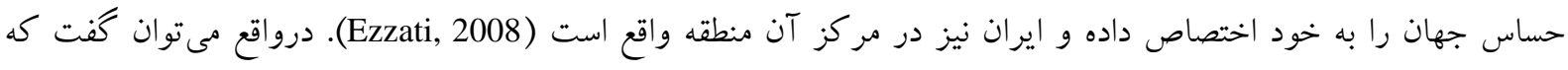

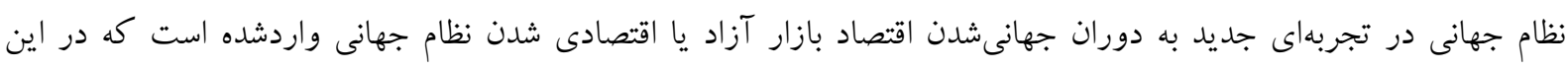

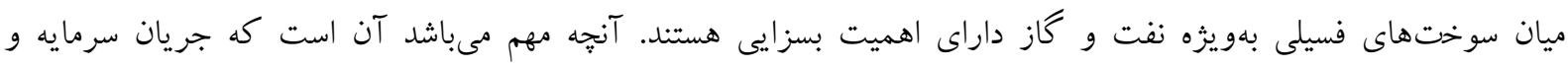

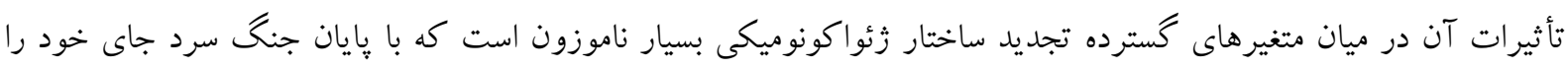

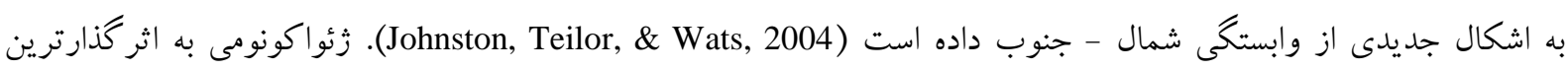
عوامل يا زيربناى سياسى، اقتصادى و جغرافيايى در محيط كشورى، منطقهاى و جهانى براى مطالعه و بررسى تصميم گيرى هاى

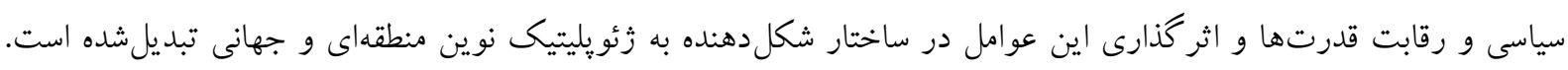

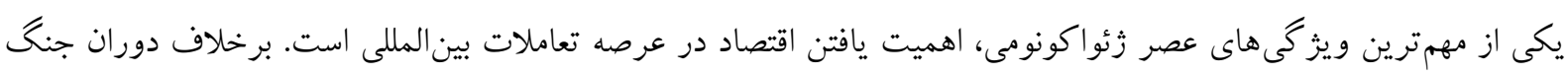



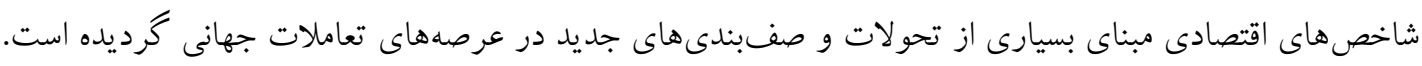

\section{نظريه بيضى استراتزيك انرزى ج جفرى كمبّ}

ديدگاه بيضى استراتزيك انرثى جفرى كمٍ در ادبيات جغرافياى سياسى، جايگاه ويزهاى دارد و به دليل اهميت يافتن

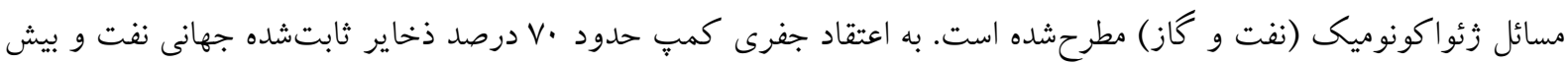

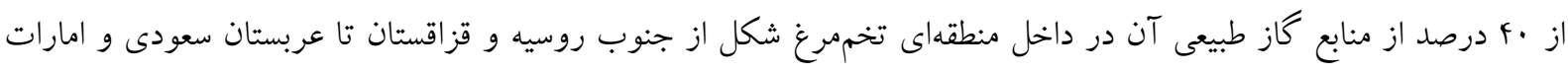

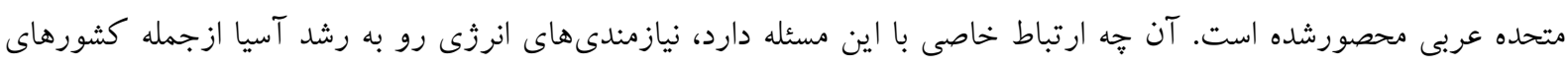

1 Geo-economic

2 Strategic Ellipse of Energy

3 Jeffrey Kamp 
جين، هند و جنوب شرقى آسيا است (Kamp \& Harcavi, 2007). بر اساس نظريه بيضى استراتزيك انرزى، منابع عظيم نفت و

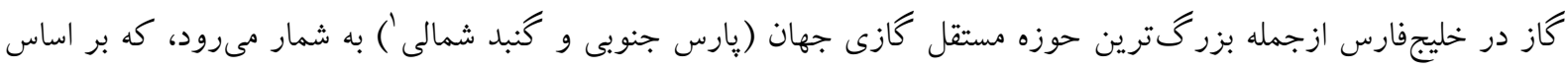

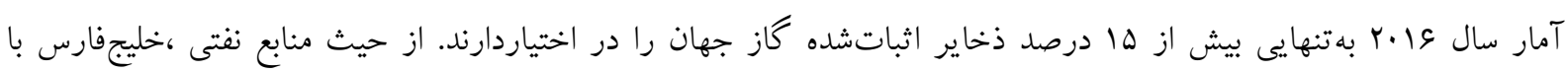

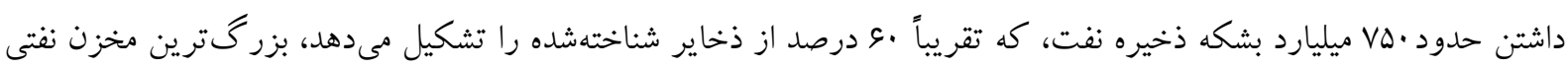

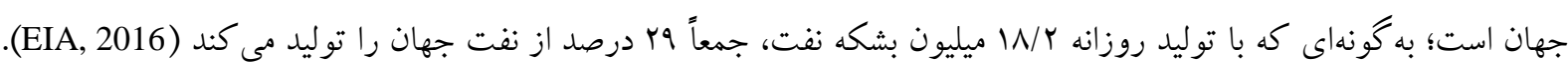

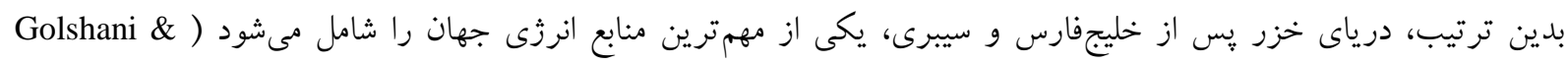

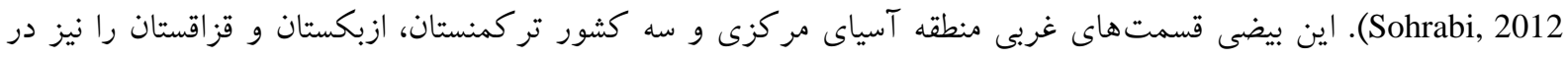

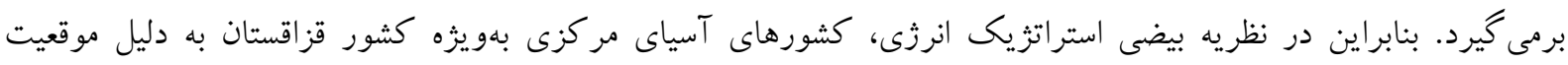

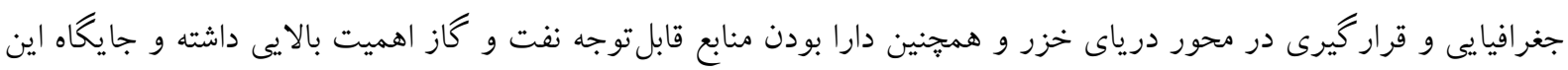

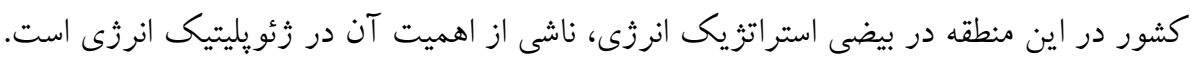

\section{محيطشناسى \\ جمهورى اسلامى ايران}

ايران به لحاظ استراتزيكى مهمترين كشور حوزه خليجفارس است. ايران بر تنكه هرمز، گلو كاه نفت جهان تسلط دارد و

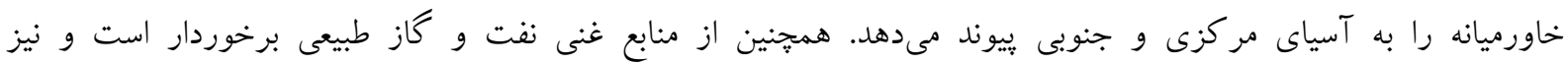

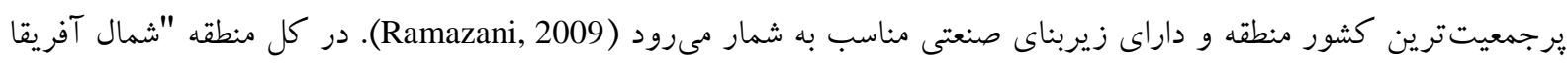

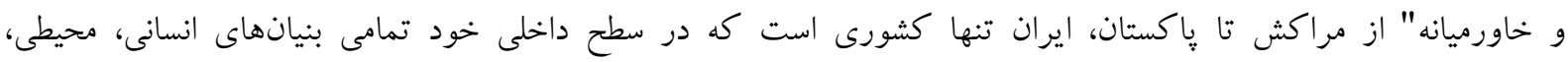

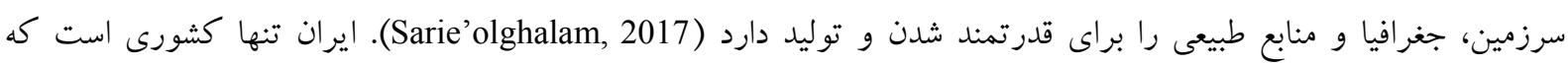

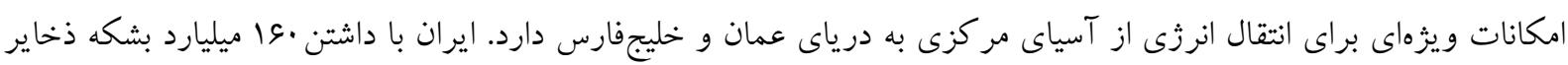

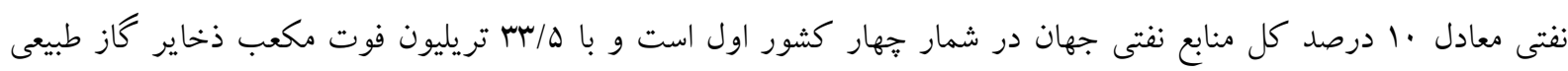
بعد از روسيه، مقام دوم را در اختيار دارد (EIA, 2017).

\section{جدول ا- ميزان توليد، صادرات و واردات نفت ايران (برحسب ميليون بشكه در روز)}

\begin{tabular}{|c|c|c|c|c|}
\hline توليد & مصرف & صادرات & واردات & سال \\
\hline$F / .9 \Lambda$ & 1/GYY & r/MKY ميليون & $r r / v 1$. & r.19 \\
\hline
\end{tabular}

منبع: (The World Fact book, 2016)

جدول r- ميزان توليد، صادرات و واردات كاز ايران ( برحسب بيليون فوت مكعب)

\begin{tabular}{|c|c|c|c|c|}
\hline سال & واردات & صادرات & مصرف & توليد \\
\hline$r .18$ & $9 / \Delta \Delta$ & $\Lambda / r \Lambda$ & If. & $M F / \Lambda$ \\
\hline
\end{tabular}

منبع: (The World Fact book, 2016)

جمهورى قزاقستان

جمهورى قزاقستان به دليل واقعشدن در بخش ميانى "اوراسيا" و شمال آسياى مركزى از موقعيتى زئواستراتزيك برخوردار

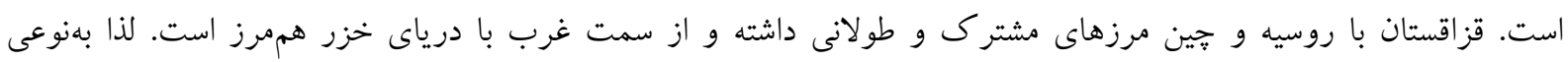




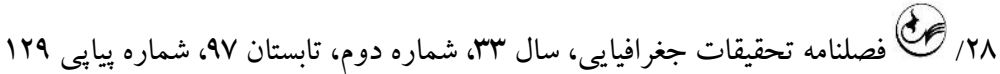

همسايه دريايى جمهورى اسلامى ايران نيز محسوب مىشود. قزاقستان كشورى عموماً هموار است كه بخش غربى و مركزى آن

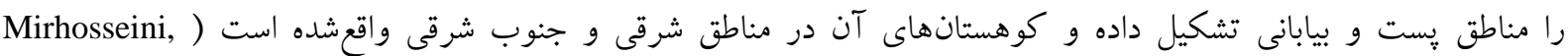
2010). قزاقستان كه بهطور رسمى در سال كهوا بهعنوان يك جمهورى سوسياليست شوروى بهطور كامل شناخته شد، يكى از

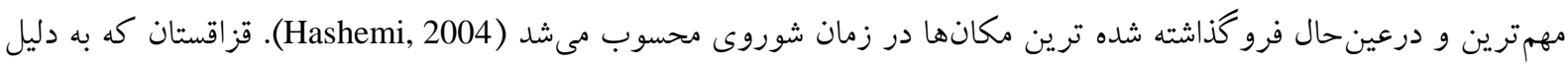

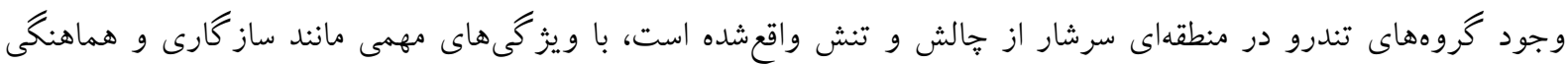
قومى و نزادى و برخوردارى از منابع طبيعى ارزشمند و ثبات سياسى، نقش اساسى را در سطوح منطقهاى و بينالملى ايفا مى كند. اين كشور همجنين بهعنوان جهارمين سازنده و توليدكنده تسليحات و تجهيزات هستهاى اتحاد شوروى و داشتن حدود ل..

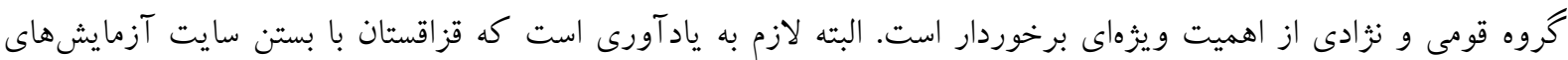

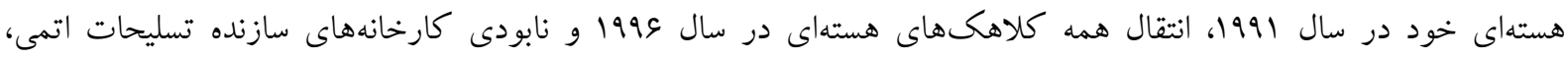

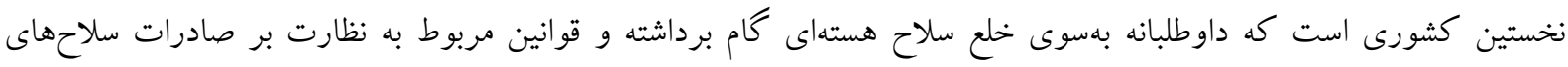

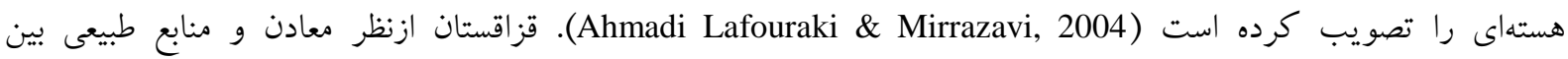

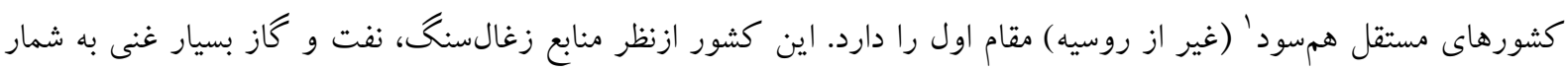

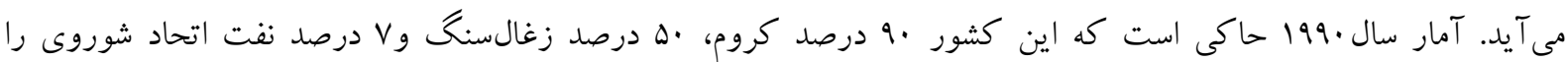

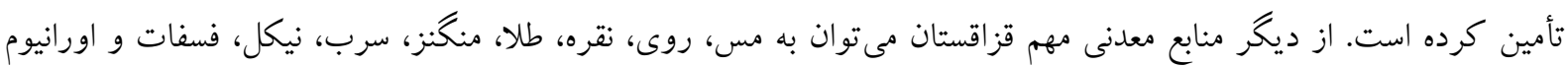
اشاره كرد.

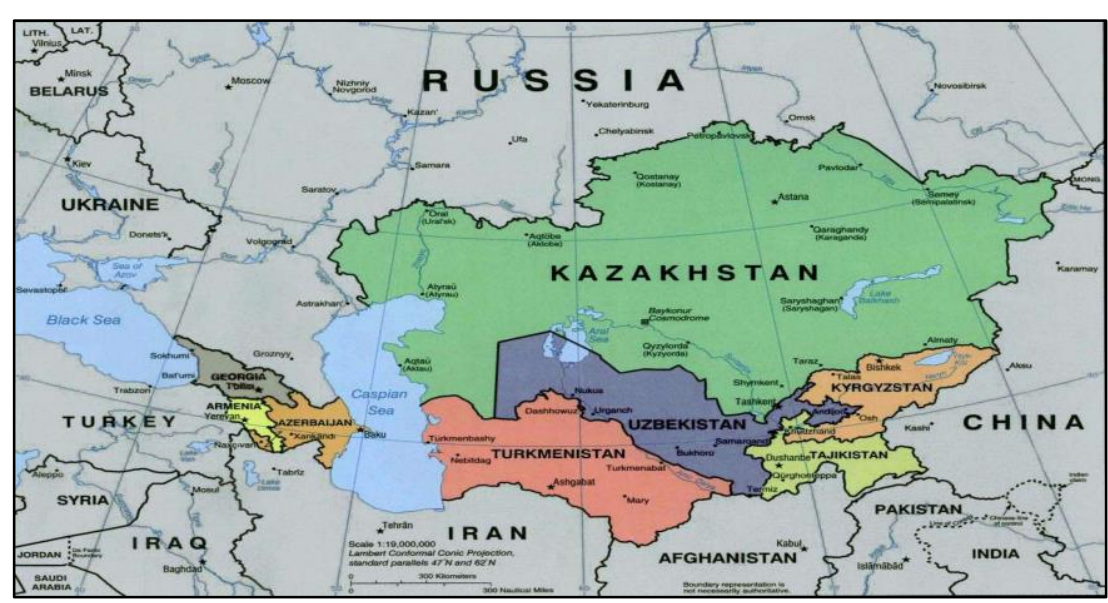

شكل 1- نقشه موقعيت قزاقستان در آسياى مركزى

(Caucasuss Studies Institute, 2011)

در سال عا.ب با صادرات بيش از هVD/YF هزار تن اورانيوم، جايكاه اول دنيا در اين زمينه را به دست آورد. ازنظر ذخاير

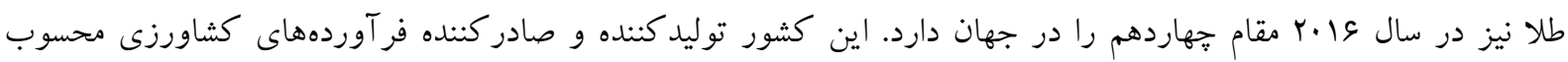

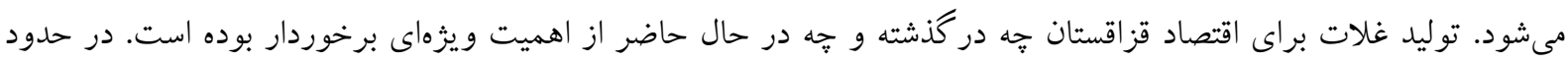

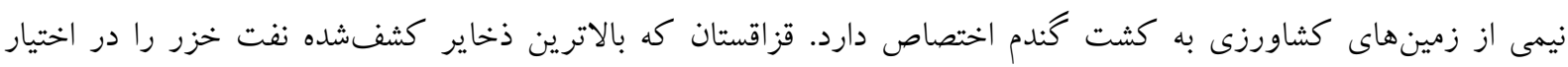

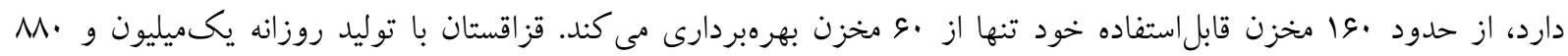

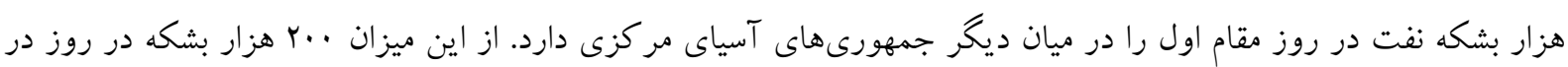


داخل كشور مصرفشده و بقيه صادر مىشود. قزاقستان با داشتن ذخاير احتمالى هـ تريليون فوت مكعب كاز از بN ميليارد

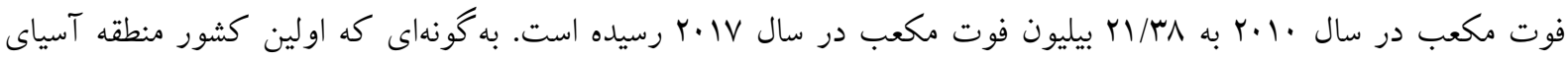

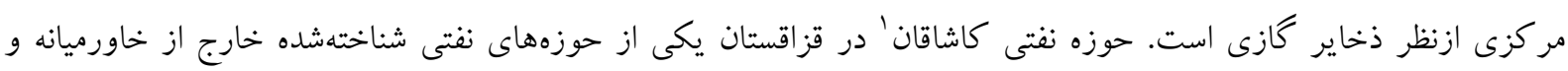

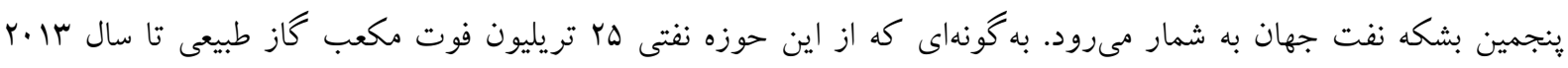

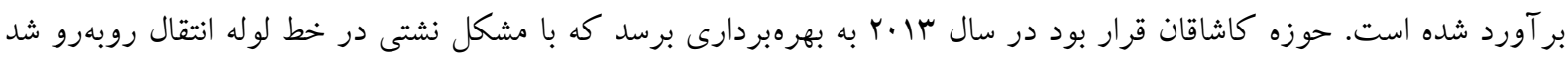

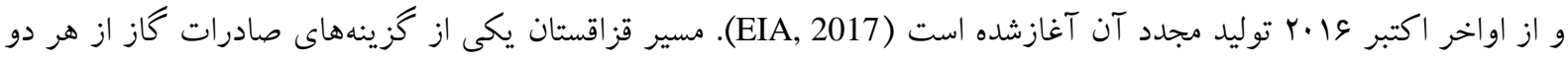

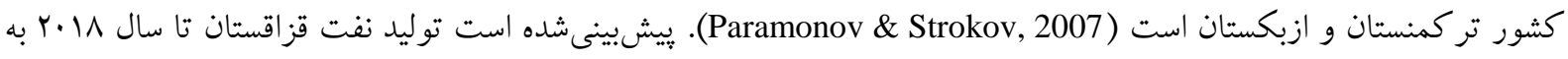

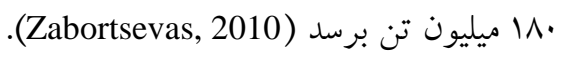

جدول r- ميز ان توليد، صادرات و واردات نفت قزاقستان (برحسب ميليون بشكه در روز)

\begin{tabular}{|c|c|c|c|c|}
\hline توليد & مصرف & صادرات & واردات & سال \\
\hline $1 / M \Lambda$. & F ب... هزار & l/rqr & $\mid f \Delta / \Lambda \ldots$ & r.IV \\
\hline
\end{tabular}

منبع: (The World Fact book, 2016)

\section{جدول ع- ميزان توليد، صادرات و واردات كاز قزاقستان (برحسب بيليون فوت مكعب)}

\begin{tabular}{|c|c|c|c|c|}
\hline توليد & مصرف & صادرات & واردات & سال \\
\hline$r \mid / \mu \Lambda$ & $|r /|$ & $1 \% / v$ & $f / V$ & r.IV \\
\hline
\end{tabular}

منبع: (TheWorld Fact book, 2016)

يافتههاى تحقيق مناسبات زئو اكونوميكى ايران و قزاقستان قزاقستان ازجمله كشورهاى درحالتوسعه منطقه است كه به دليل برخوردارى از در آمدهاى ارزى حاصل از فروش نفت،

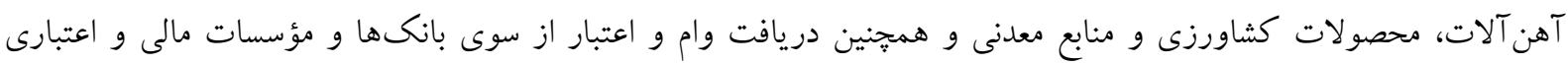

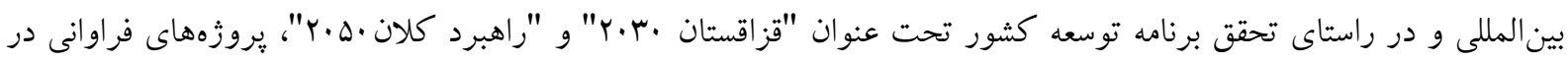

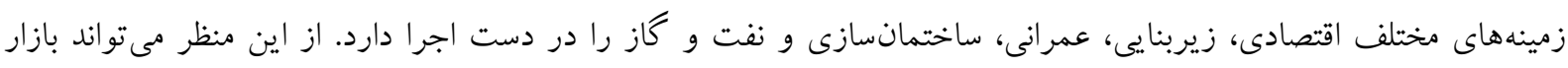

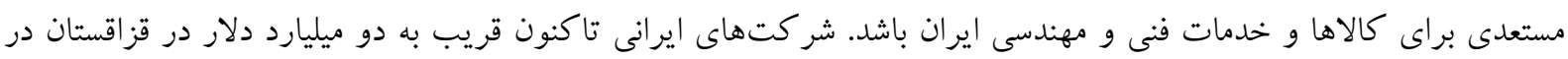

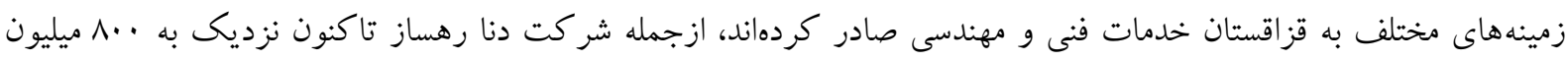

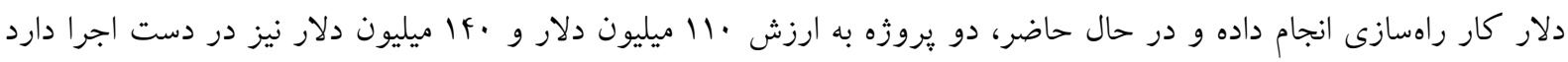

.(Economic Siteof the Ministry of Foreign Affairs, 2018)

$$
\text { حملونقل و ترانزيت }
$$

حملونقل ازجمله مهمترين وابستكى هاى جغرافيايى و زئويليتيكى ايران و قزاقستان، مزيتهاى موقعيت زئويليتيكى -

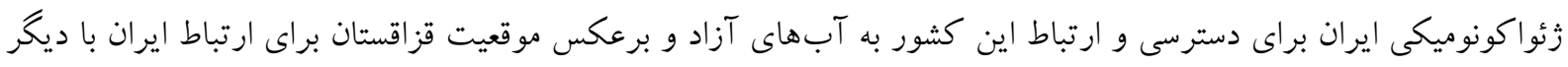

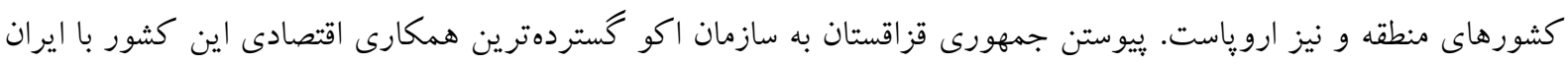

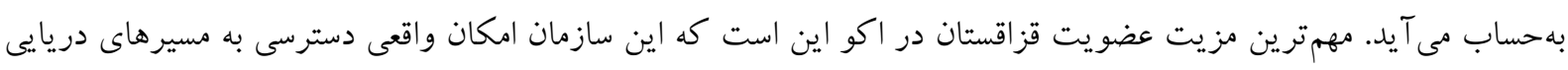




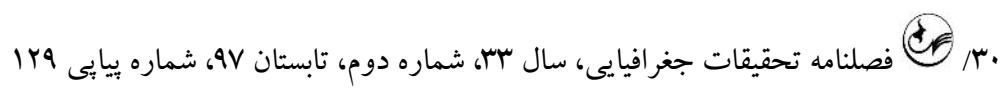

را در درياى مديترانه و خليجفارس و درياى عمان براى اين كشور فراهم مىسازد (Marat, 2008). سازمان همكارى اقتصادى

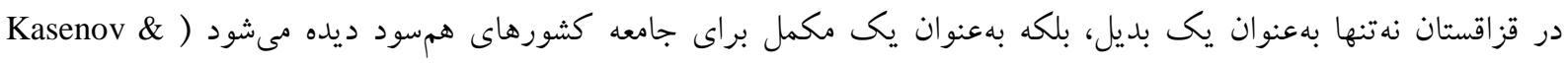

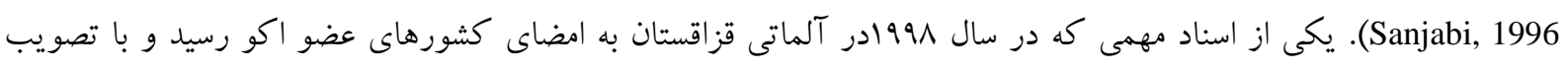

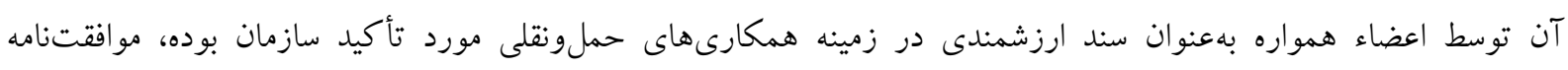

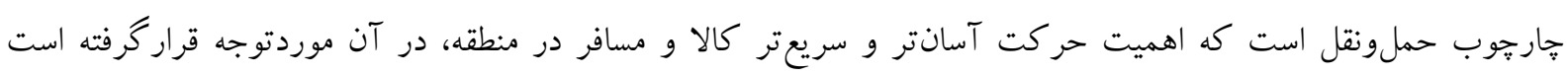

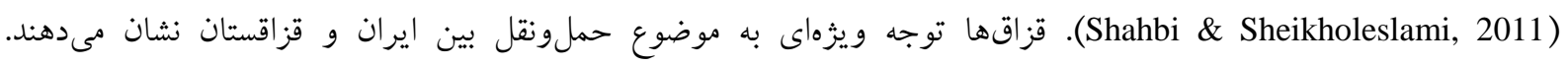

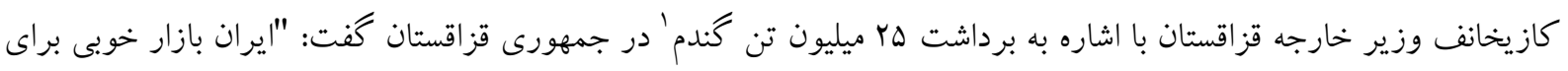

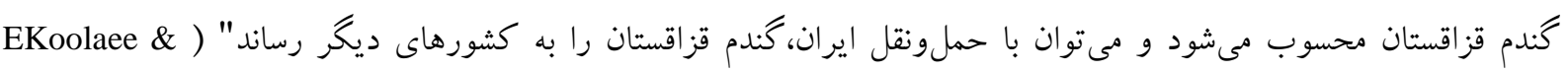

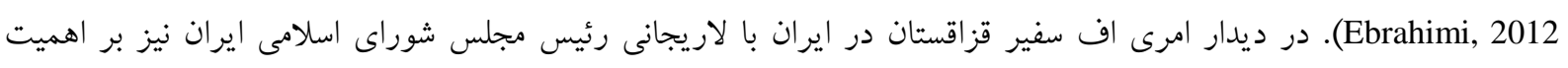

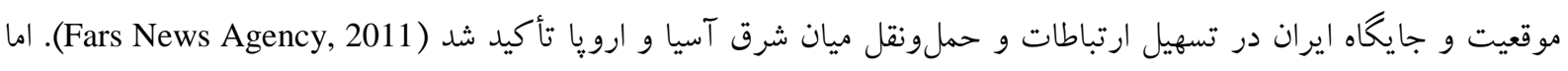

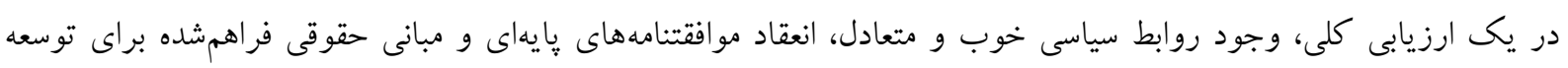

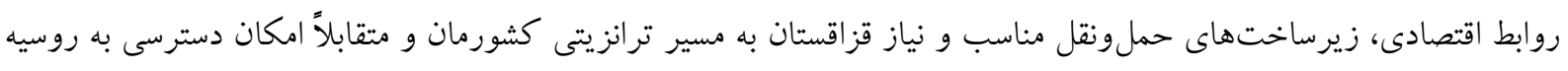

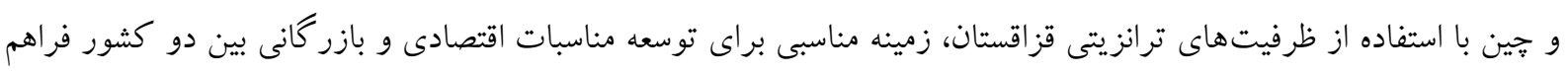

كرده است (Economic Siteof the Ministry of Foreign Affairs, 2018).

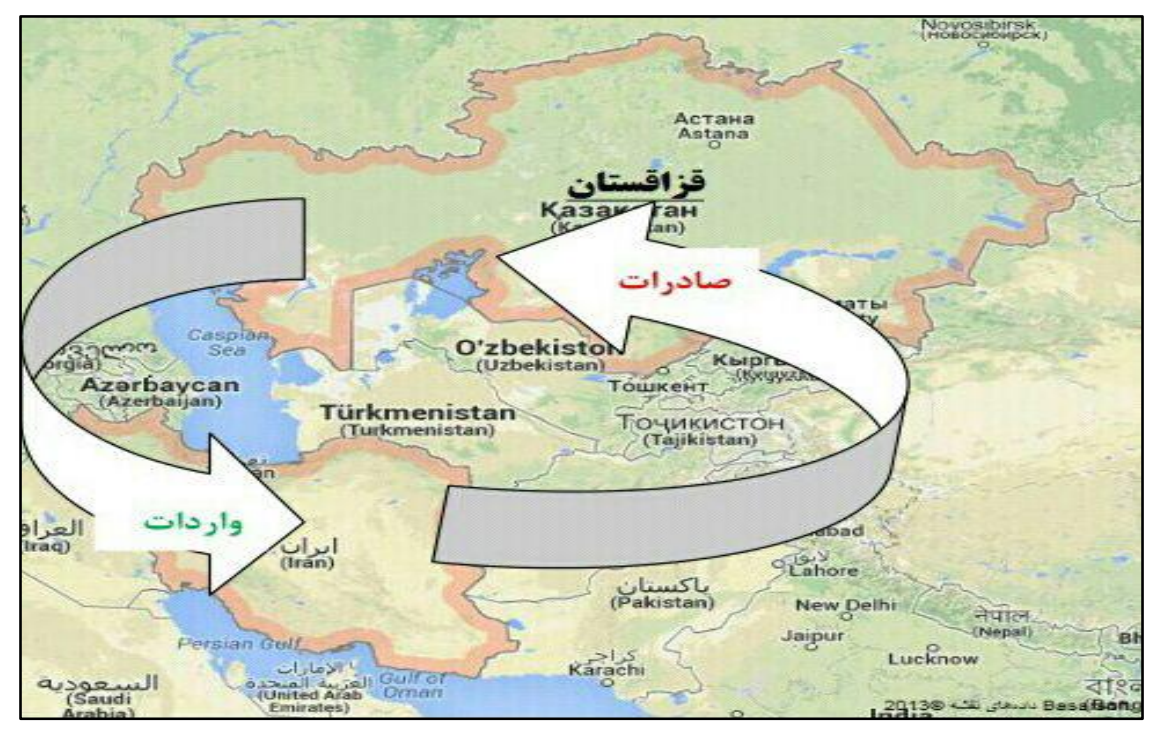

شكل r- نقشه مسير ترانزيت مبادلات كالا بين ايران و قزاقستان

(http://import-export.ir/14/Kazakhstan.html)

تجارت و مبادله كالا

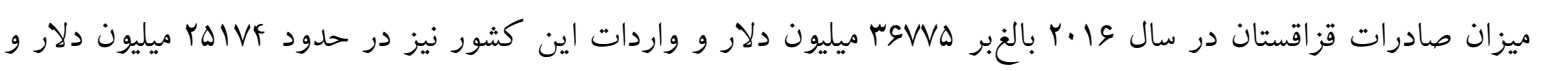

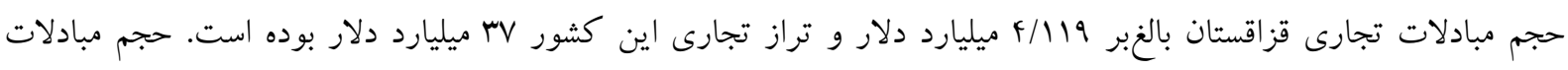

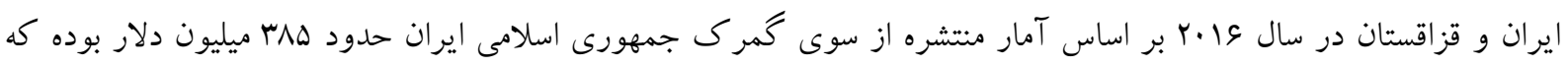

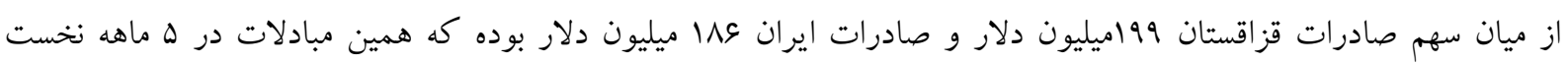

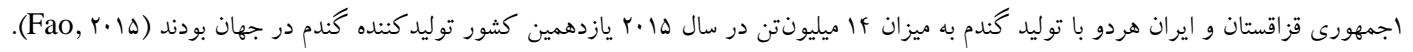




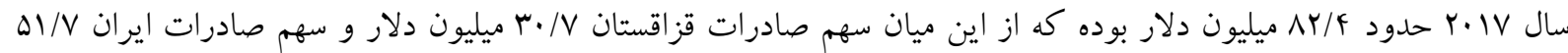
ميليون دلار بوده است (Economic Site of the Ministry of Foreign Affairs, 2018). عمدهترين محصولات صادراتى ايران شامل انواع خشكبار، يسته، خرما، سيمان، محصولات يتروشيمى، انواع مصالح ساختمانى، مواد غذايى، ميوه و صيفىجات، مواد شوينده، انواع رنگ ها و محصولات لاستيكى و يلاستيكى هستند. عمدهرين اقلام وارداتى ايران نيز كندم، جو، آهن آلات و فولاد، دانهاى روغنى مانند آفتابكردان و كلزا و قراضه باترى و ساير محصولات غير فولادى است ( Trade Promotion (Organization of Iran, 2015 . ارتباطات تجارى ايران قزاقستان در طى دو دهه كذشته داراى فراز و نشيبهاى زيادى بوده

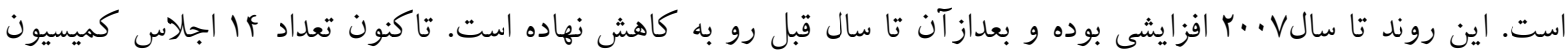

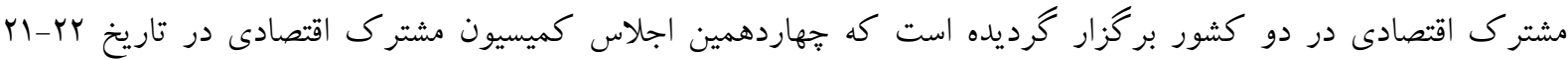

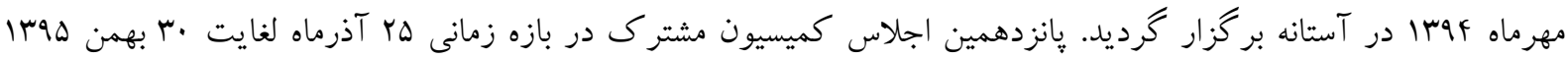

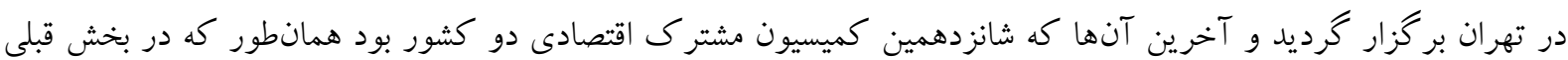
اشاره شد در ها اسفندماه سال عqسا در قزاقستان بركزار گرديده است.

جدول 0- مبادلات كالا بين ايران و قزاقستان (ارزش: ميليون دلار)

\begin{tabular}{|c|c|c|c|c|c|c|}
\hline 1ras & $11 \% 90$ & Irgf & (rq & irgr & $\mid r q 1$ & سال \\
\hline$s \cdot / f$ & $1 \wedge \Delta$ & ITs & Yl. & rl. & 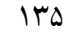 & صادرات \\
\hline $1 \cdot \Delta / \Delta$ & 199 & VA & 189 & $\Delta F$ & $1 \wedge \varepsilon$ & واردات \\
\hline 11/rs & $10 / r q$ & 49 & M & Irs & -01 & تراز تجارى \\
\hline MHF & rAF & TrM & ґ^q & raf & MrI & تجارت خارجى \\
\hline
\end{tabular}

منبع: (Tehran Chamberog Commerce Industries Miniesand Agriculture, 2015)

انرزى و خطوط انتقال انرزى

در نخستين ماههاى گس از فروياشى شوروى، ساختن لولههاى انتقال نفت و كاز حوزه خزر مسير منطقى اقتصادى خود يعنى ارزانترين و سريعترين مسير را جستجو مى كرد و حتى كشورهاى حوزه خزر به توافقى براى همكارى نيز دست يافنند. مسير ايران كوتاهترين، ارزانترين و سريعترين مسير انتقال نفت و كاز درياى خزر به بازارهاى مصرف است، فشار آمريكا بر كشورهاى منطقه، برخلاف منطق اقتصادى و همواره در جهت آن بوده كه هيج لوله نفتى يا مسير ترانزيتى از ايران عبور نكند.

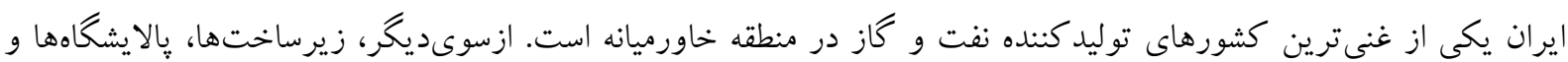
خطوط انتقال انرزى امتياز مناسبى جهت ارائه يك نقش فعال براى ايران در منطقه ايجاد كرده است. وجود خطوط لوله شمال به جنوب و همجوارى ايران با جمهورىهاى آسياى مركزى، فرصت خوبى براى ايران در معامله خريدوفروش با اين جمهورىها فراهم آورده، موقعيتى كه مىتوان از آن در تعميق بيوندهاى سياسى و اقتصادى و ارائه يك بازى فعال استفاده كرد، كه بى ترديد داراى ابعاد امنيتى غيرقابلانكار است (Mottaghi \& Hemmatkhah, 2008). اما رقابت قدرتهاى منطقهاى و فرامنطقهاى براى پيشنهاد مسيرهاى غيرمنطقى انتقال انرزى براى كسب نفوذ سياسى و حفظ برترى خود بر منطقه همجنان ادامه دارد. از يكىسو روسيه با منحصر كردن تماممسيرهاى صادرات از سرزمين خود، مىخواهد نفوذ و كنترل سنتى خود را بر كشورهاى تازه استقلاليافته حفظ كند، از سوى ديخر آمريكا كه بهعنوان رقيب جدى در منطقه، طرفدار مسيرهايى است كه در راستاى اهداف درازمدت و علائق زئويليتيك خود، به محدود كردن نقش واقعى و اصولى ايران در منطقه منجر شود ( Etaat \&

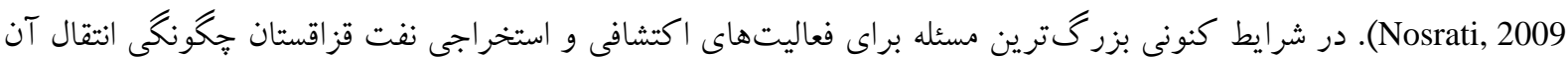


Yr/

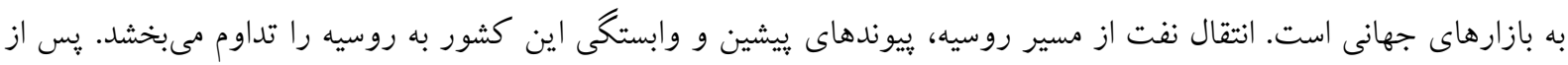

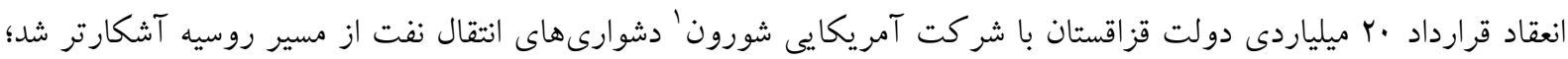

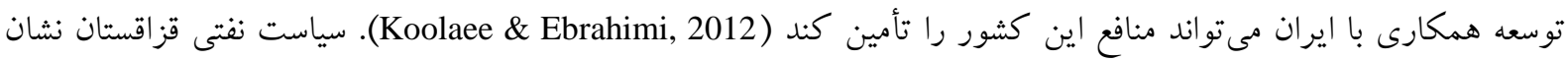
مىدهد اين كشور جوياى روابط نزديك با روسيه است و از خطوط نفتى اين كشور جهت صدور نفت خود بهره مىبرد. علاوه بر اين قزاقستان همكارى شر كتهاى نفتى غربى را جهت ارائه نفت خود به دنيا تشويق مى كند. همجنين امكان همكارى با

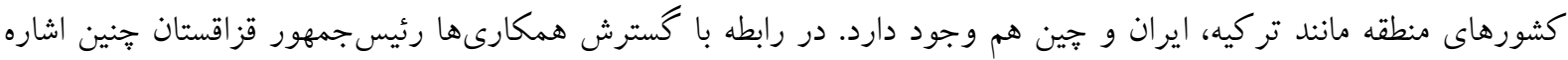

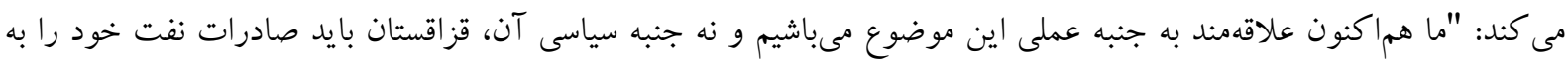

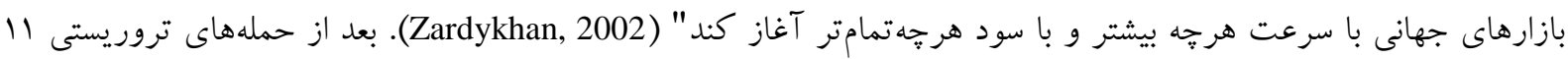

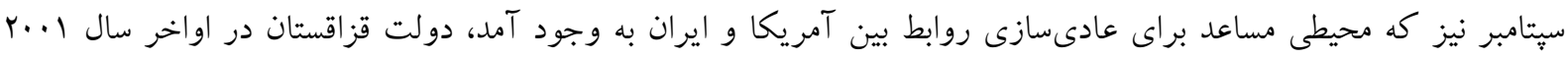

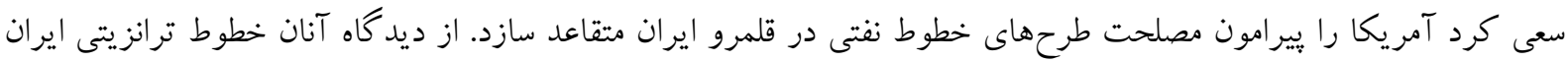

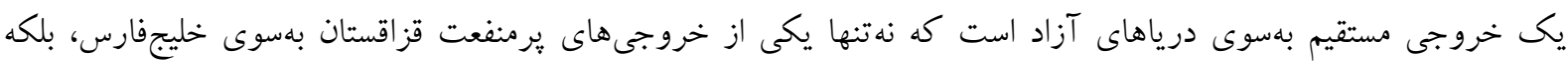

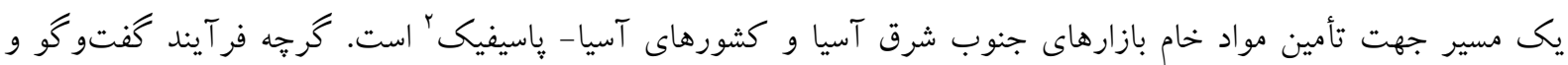

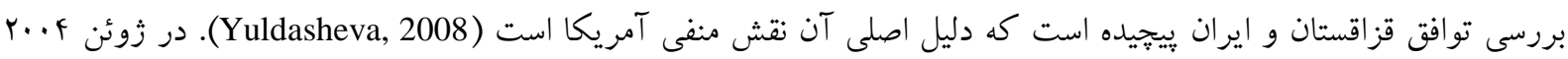

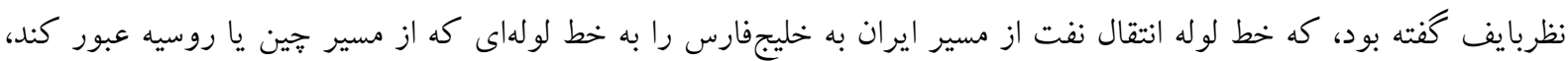

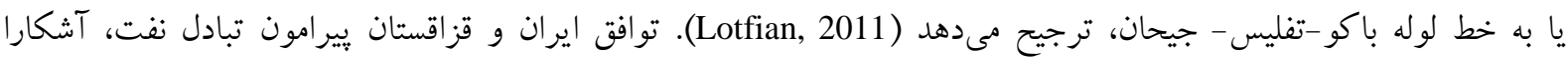

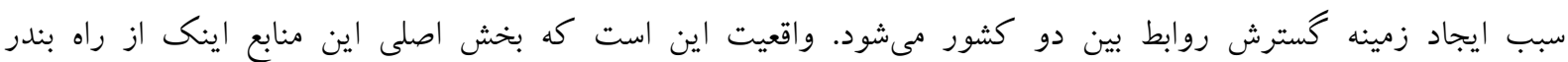

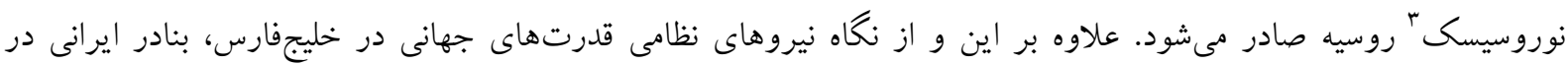

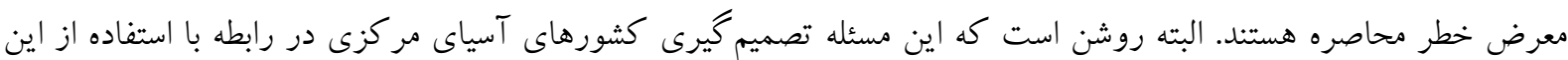

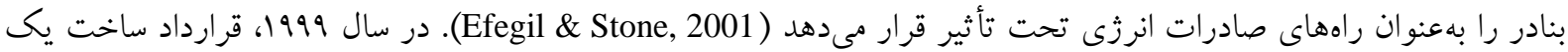

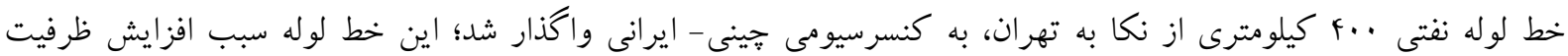

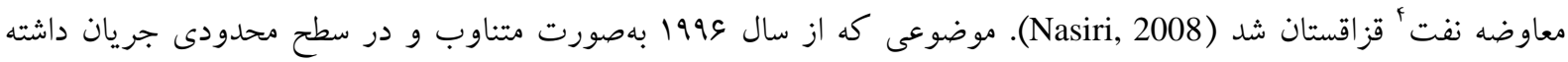

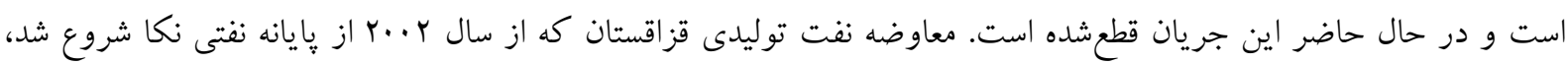

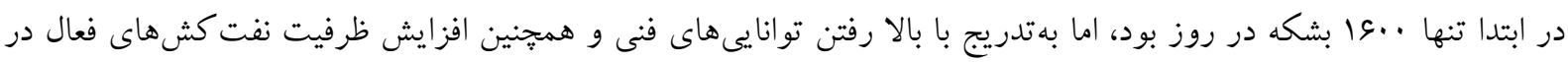

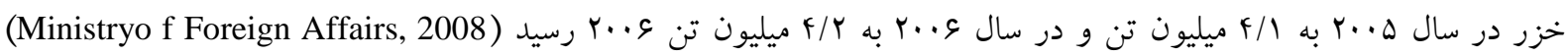
.(Ministry of Foreign affairs kazakhstan, 2010: 120) 


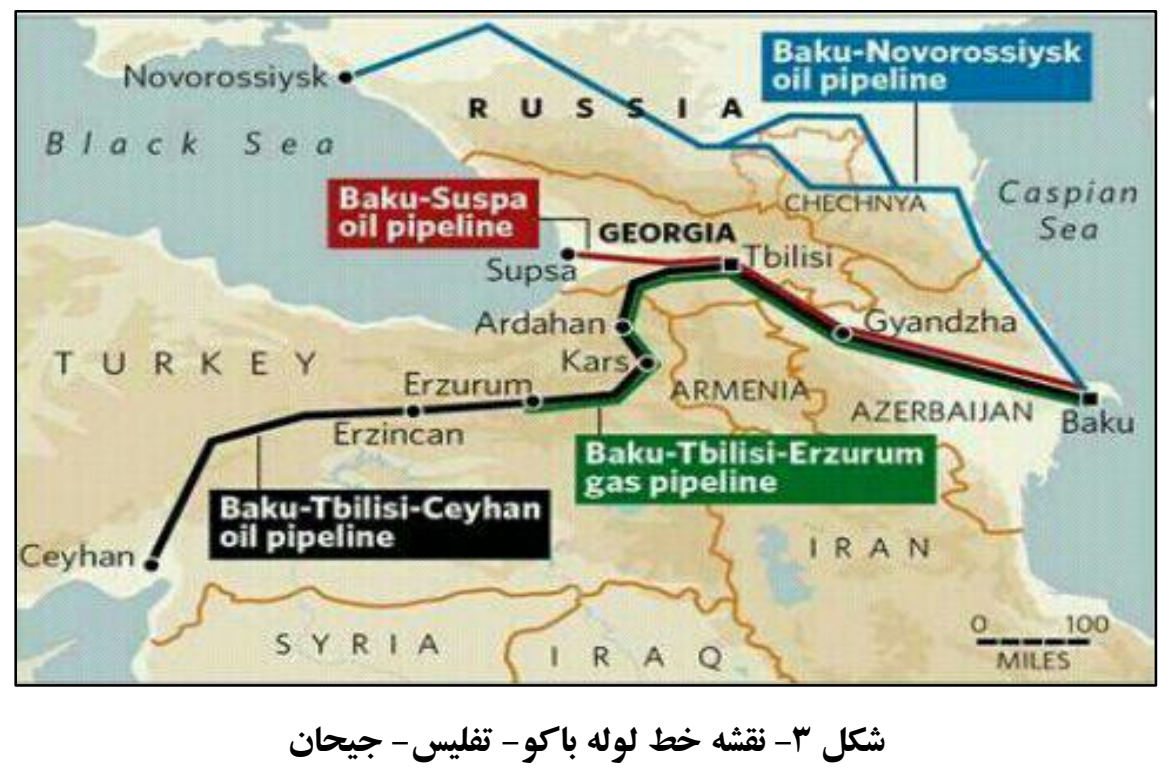

(Kaiser \& Pulsipher, 2007)

منوجهر متكى وزير خارجه وقت ايران در نشست خبرى مشترك با وزير حملونقل و ارتباطات قزاقستان گفت: "ايران توانسته ظرفيت انتقال نفت از اين راه (معاوضه نفت) را تا ..ه هزار بشكه در روز افزايش دهد"، اما قزاقستان از همه ظرفيتهاى ايران در اين زمينه استفاده نكرده است. بخش اندكى از نفت قزاقستان به كمى كشتىها از راه درياى خزر روانه

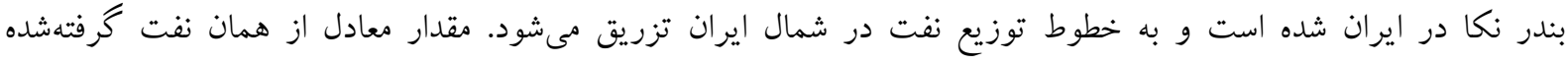

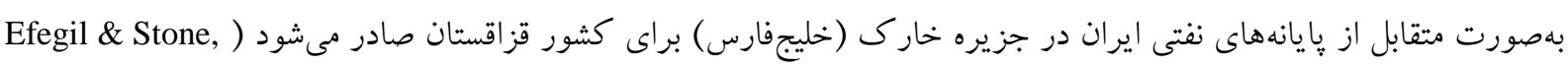

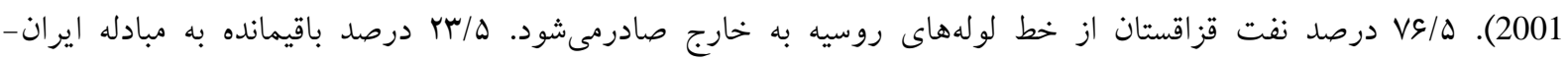

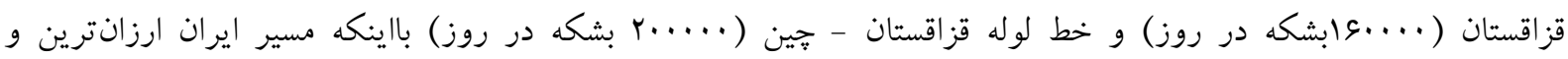

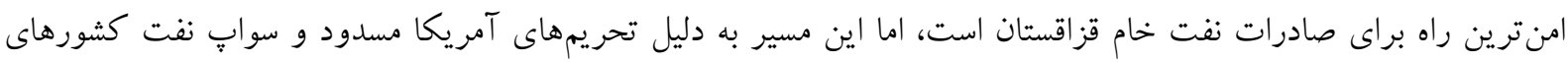
حاشيه خزر از دوره احمدى نزاد متوقفشده است (Martin \& Miguel, 2010).

\section{محدوديتهاى حضور جمهورى اسلامى ايران در آسياى مركزى}

فروياشى شوروى از يكسو فرصتهايى فراوان در ابعاد امنيتى، اقتصادى و فرهنگى براى ايران ايجاد كرد و از سوى ديكر،

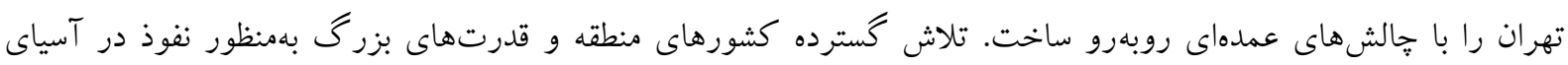

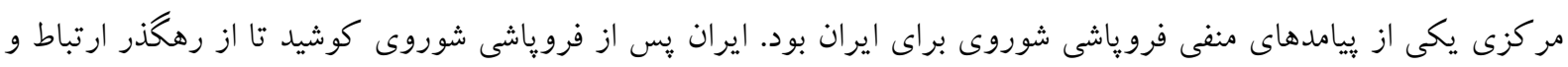

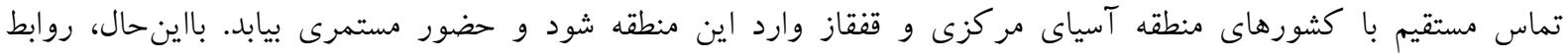

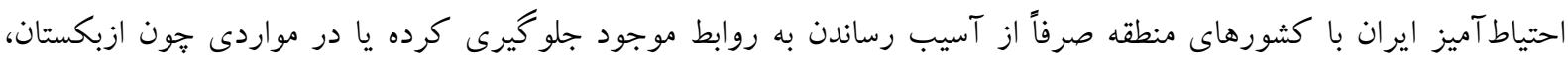
روابط نامناسب را بهبود بخشيده است. به نظر مىرسد بهجز ييوستن كشورهاى منطقه به سازمان اكو و عضويت ناظر ايران در

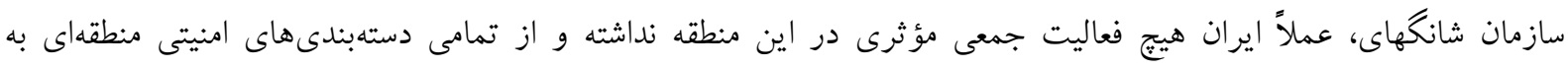

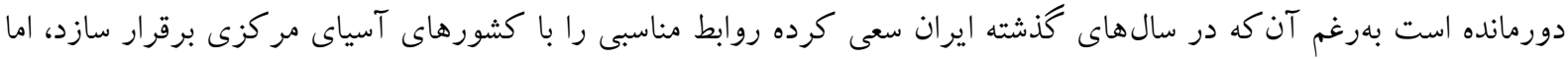

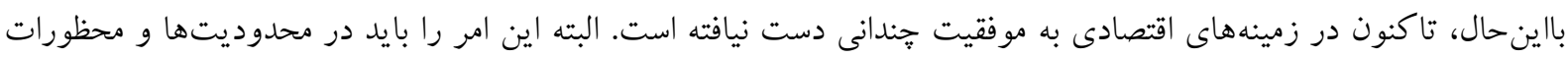

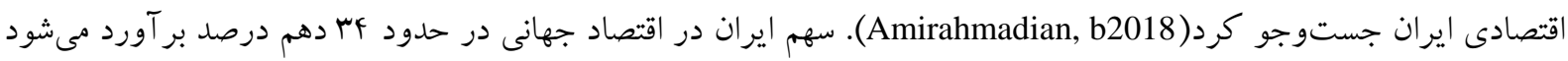

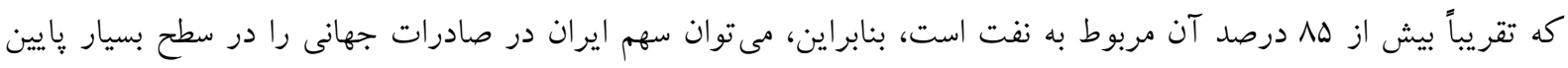




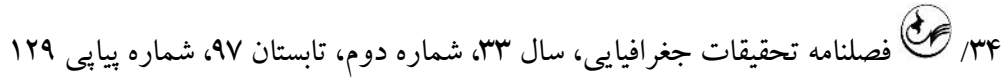
ارزيابى كرد. منطقه قفقاز و آسياى مركزى به لحاظ موقعيت سياسى و ظرفيتهاى بالقوه انرزى، از گذشته هاى دور موردتوجه

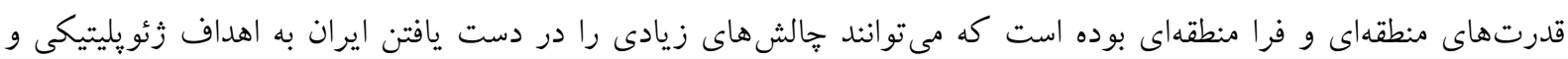

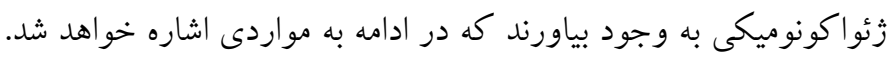

\section{مداخله قدرتهاى منطقهاى و فرا منطقهاى در آسياى مر كزى}

سياست روسيه در آسياى مركزى، داراى ماهيت دو گانهاى است. از يكسو مسكو به دنبال حضور قوىترى در منطقه

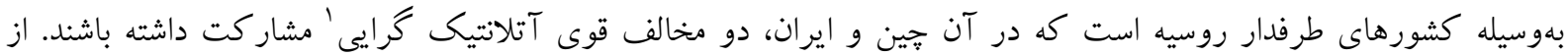

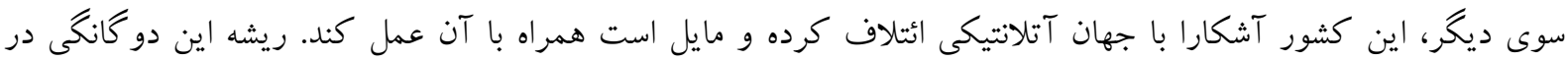

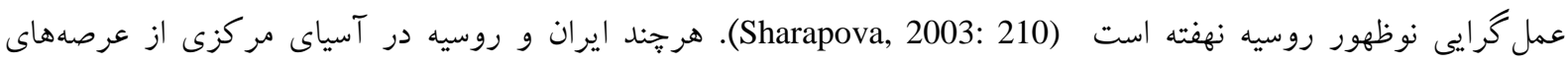

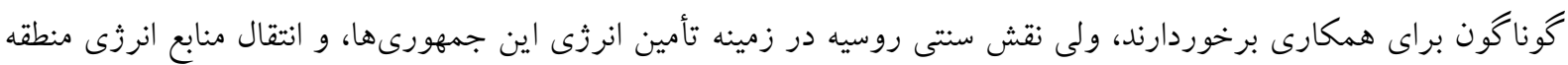

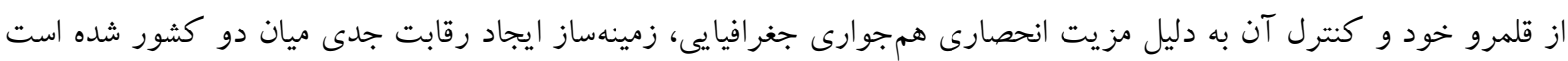

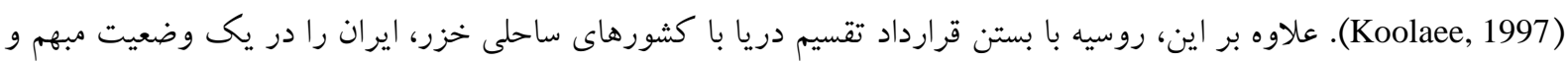

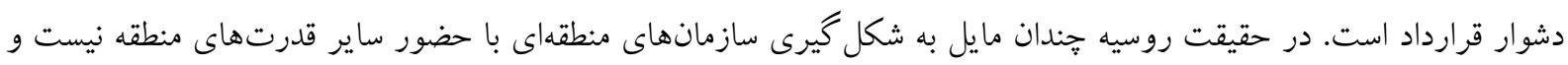

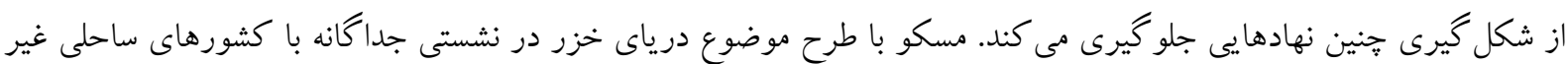

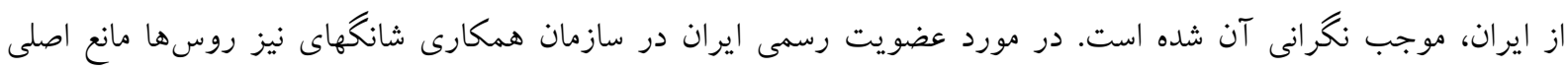

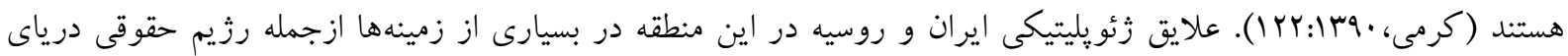

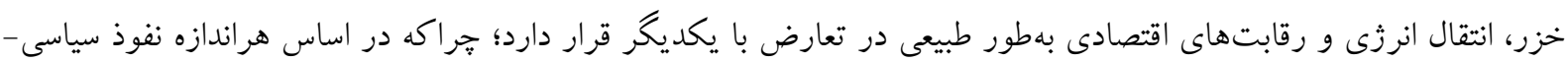

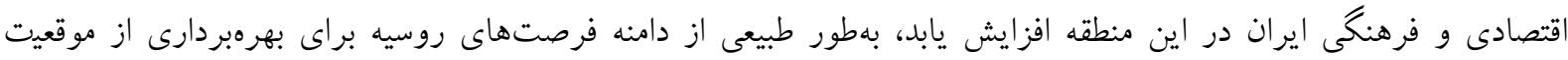

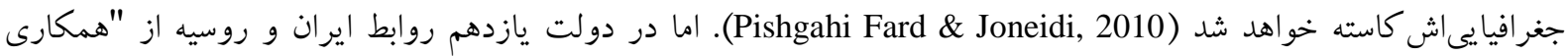

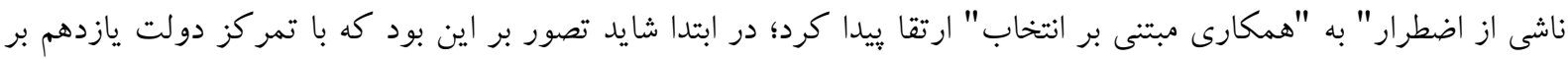

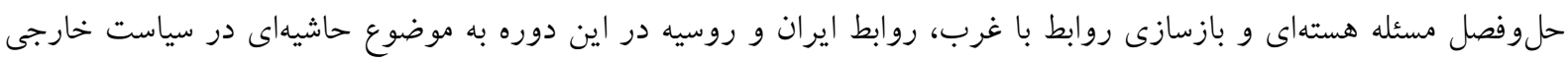

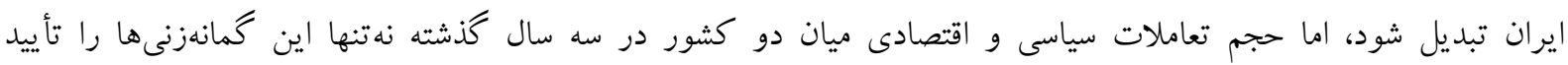
نمى كند، بلكه حكايت از اراده سياسى رهبران ايران براى حفظ و ارتقاى روابط با همسايه قدرتمند شمالى يعنى روسيه دارد،

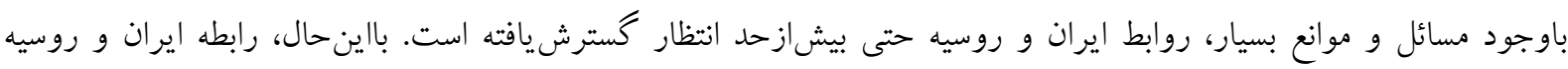

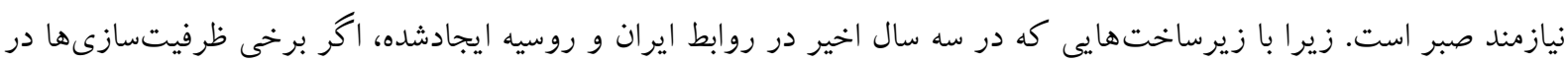

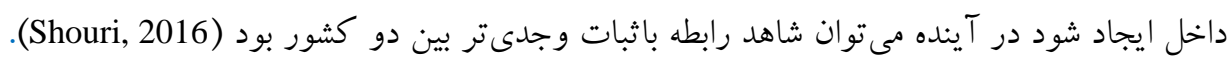

\section{ايالاتمتحده آمريكا}

قزاقستان از زمان استقلال آن روابط سياسى، اقتصادى و امنيتى محكمى را با مجموعه وسيعى از كشورها دنبال مى كند. بر

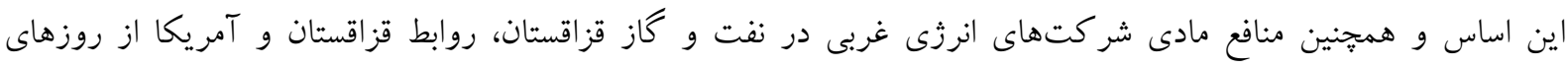

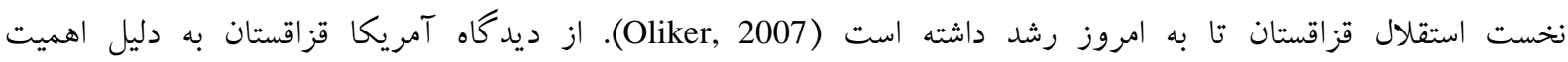

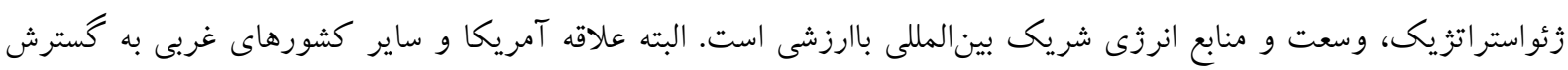


نفوذشان در قزاقستان بيشتر به اين دليل است كه اين كشور توانايى استراتزيك و نظامى زيادى دارد. قزاقستان فراتر از …

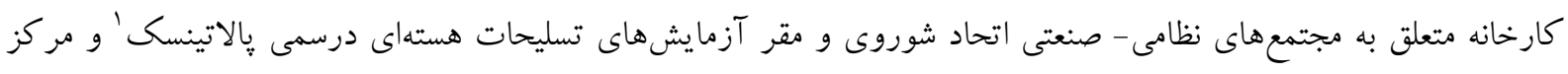

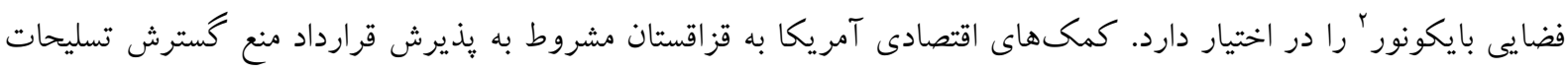

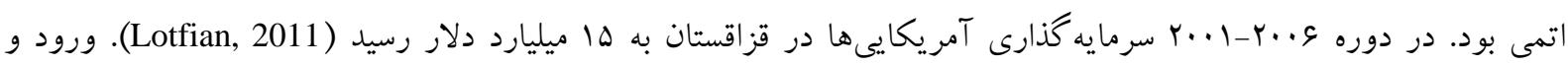

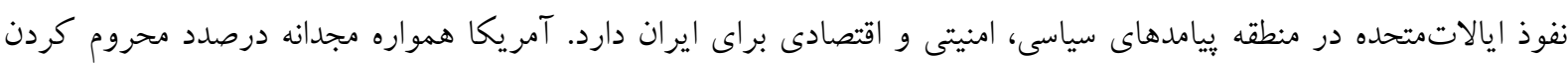

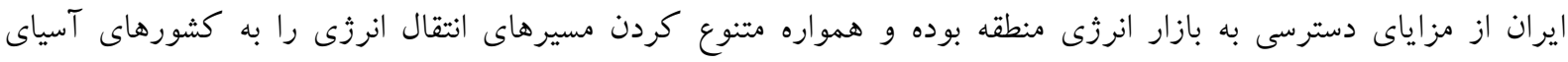

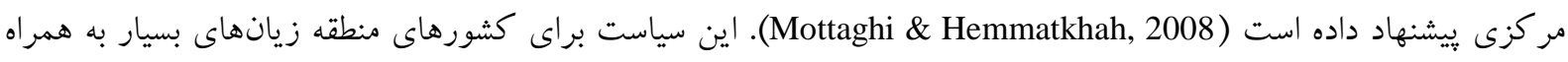

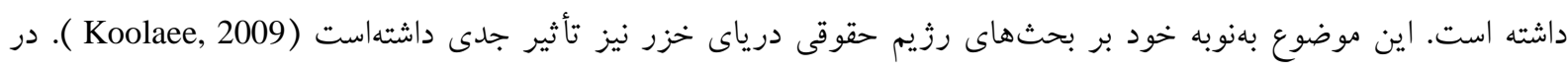

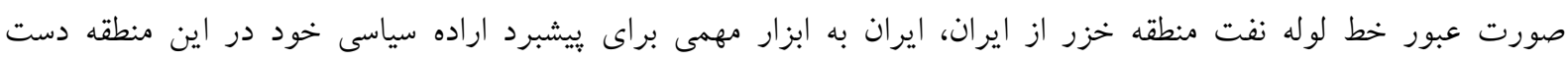

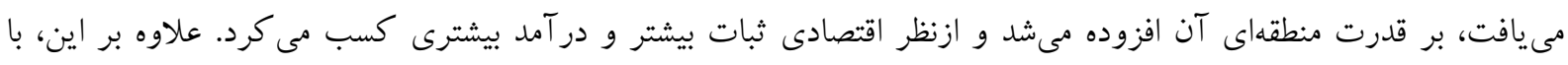

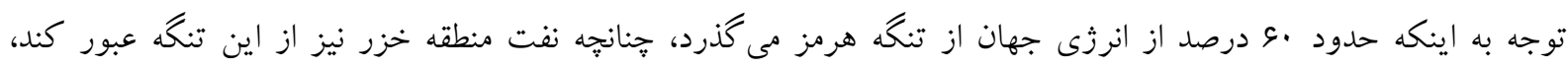

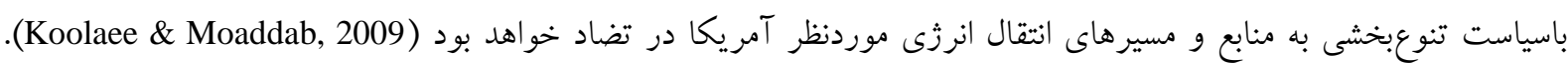

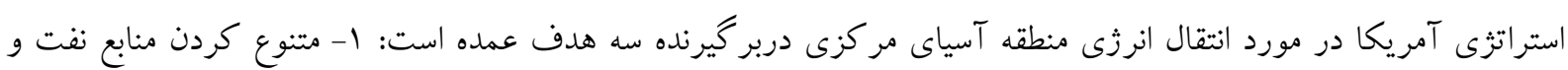

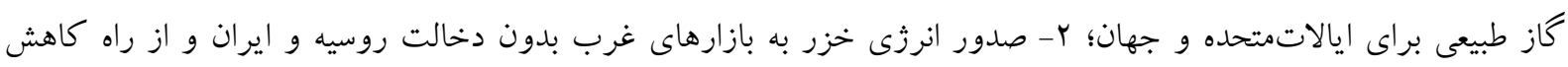

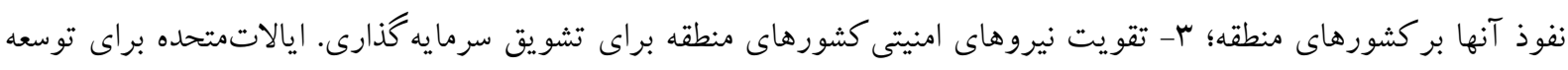

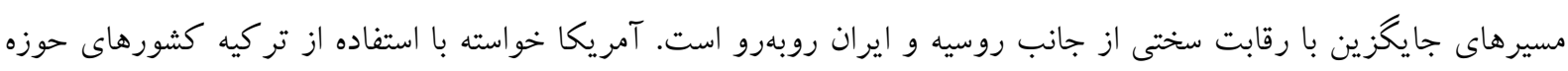

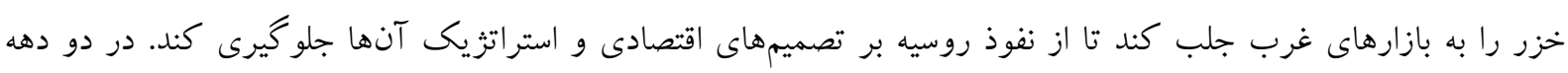

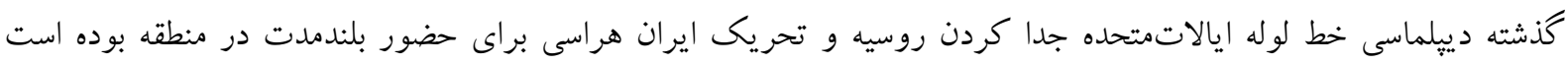

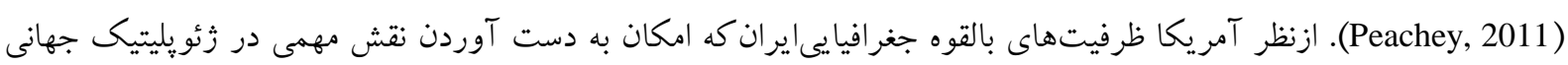

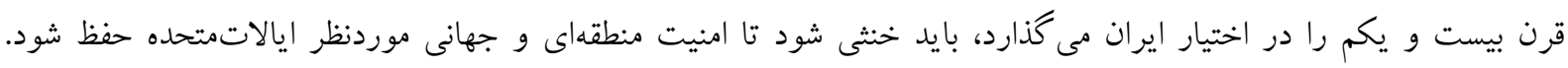

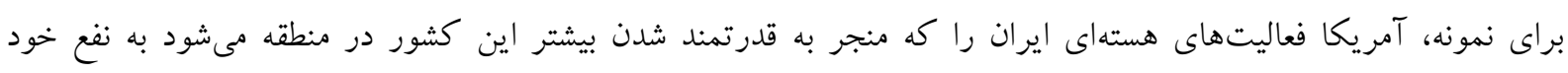

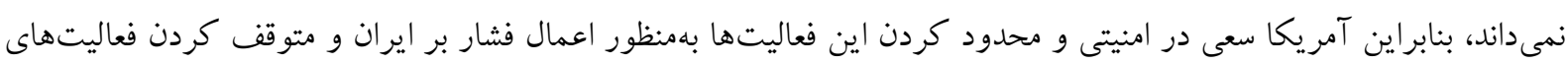

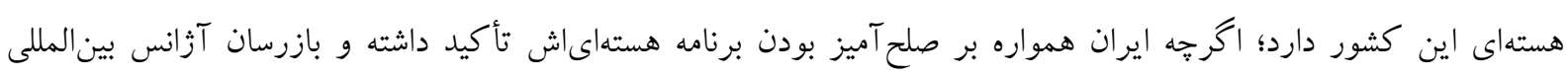

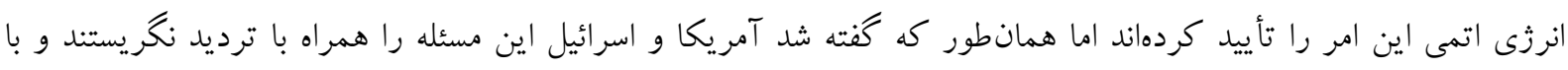

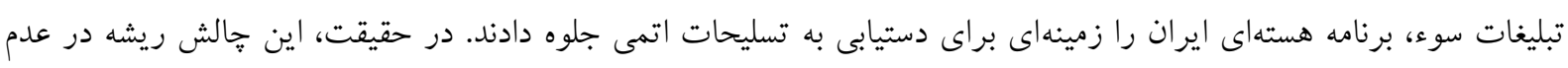

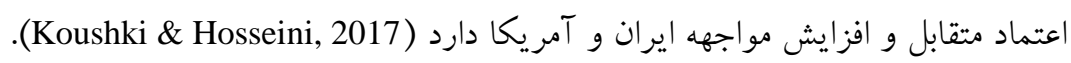

\section{جين؛ برهم زننده معادلات استراتزيكى و زئو اكونوميكى در آسياى مركزى}

سياست جين در منطقه آسياى مر كزى را نمى توان خارج از ييشينه تاريخى آن بررسى كرد. جين در سالهاى •و به منطقه

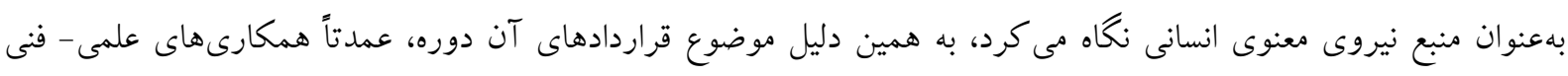

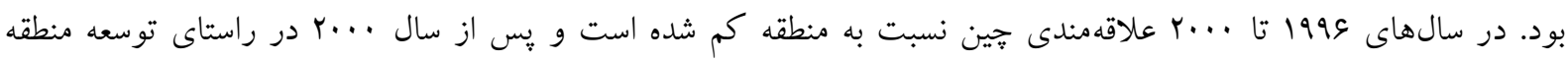

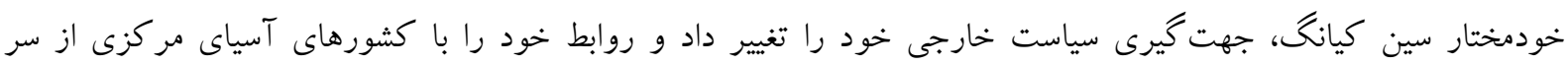




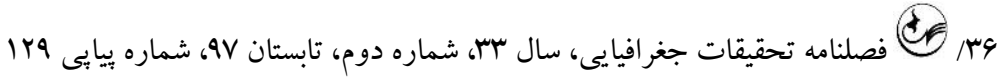

كرفت. جين از سال ه.r سرمايه گذارىهاى خود را در منطقه آغاز كرد و در حال حاضر، يكى از بازيكران مهم زئويليتيك

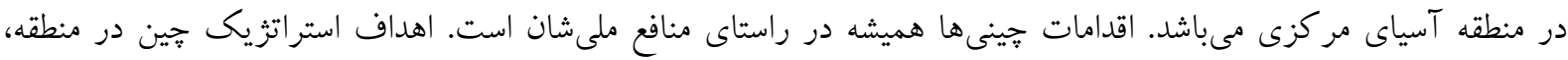
حلوفصل مشكلات مرزى، تأمين امنيت در مناطق مرزنشين و حفظ تعادل زئويليتيكى در منطقه مىباشد. جين در حال حاضر،

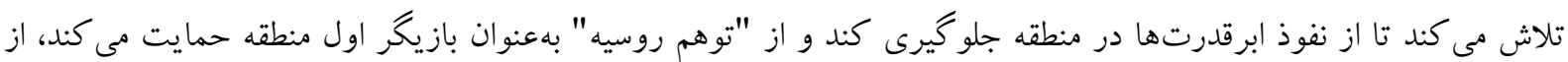

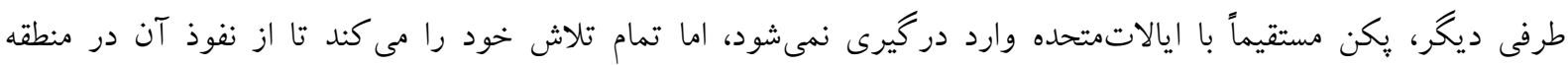

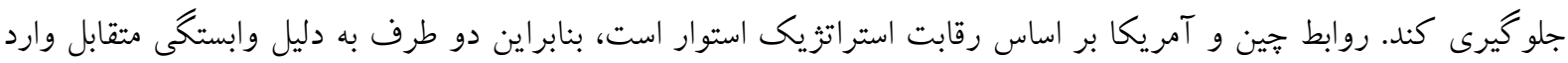

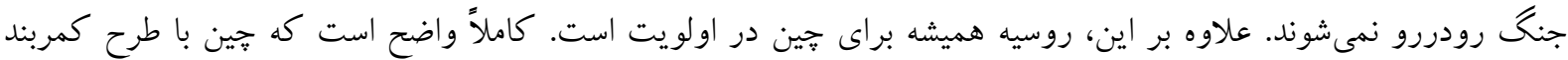

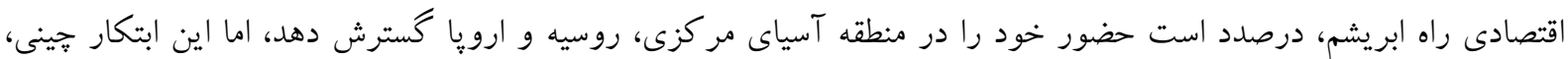

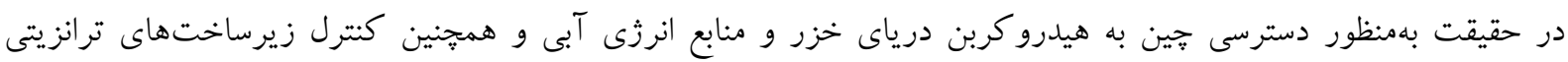

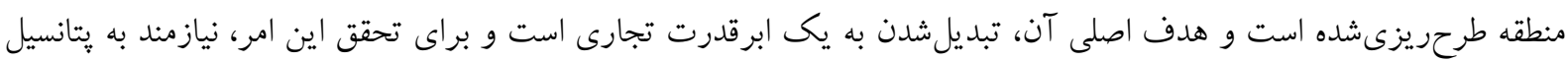

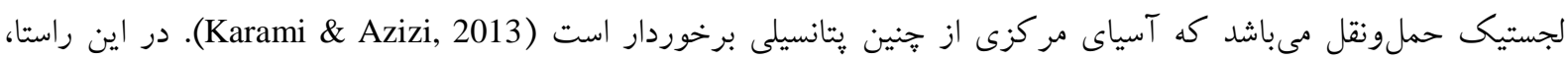

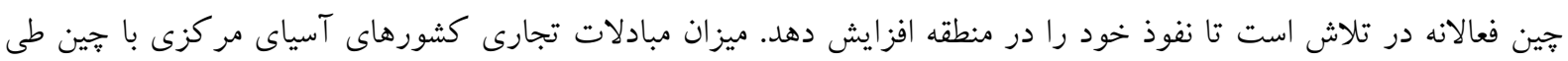

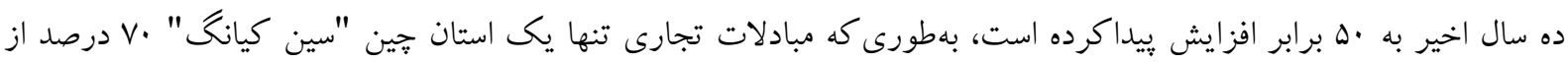

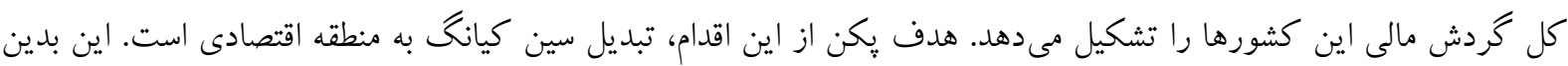

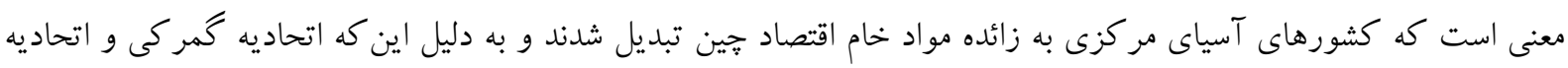

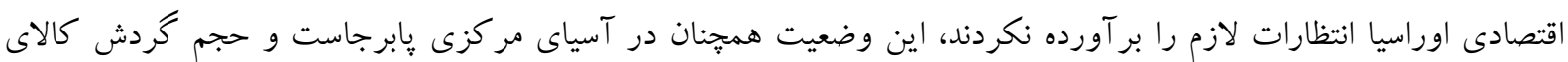

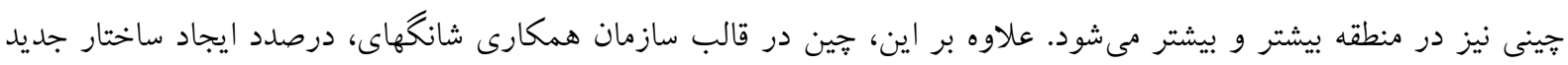

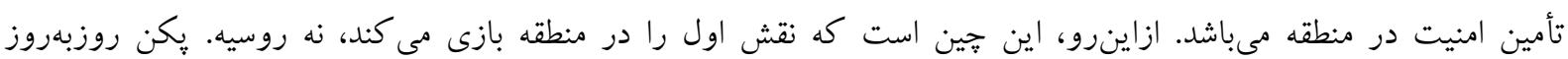

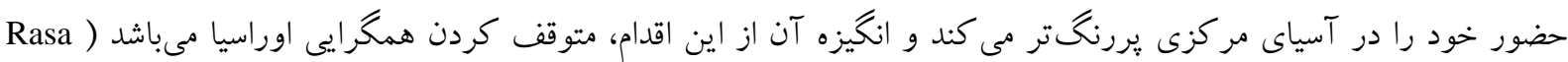

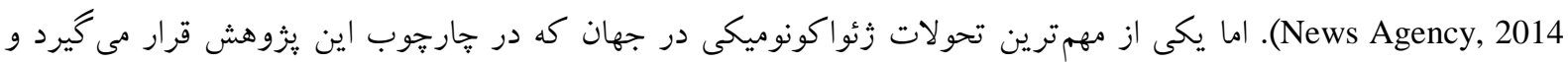

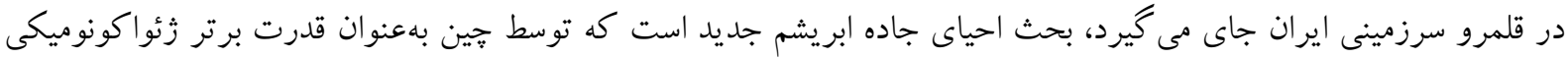

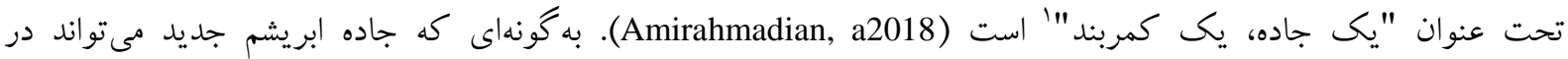

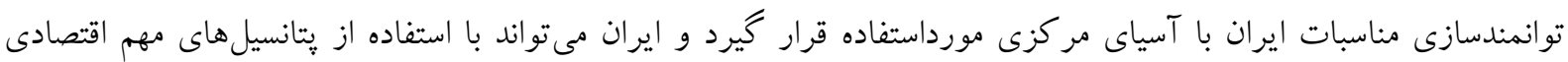

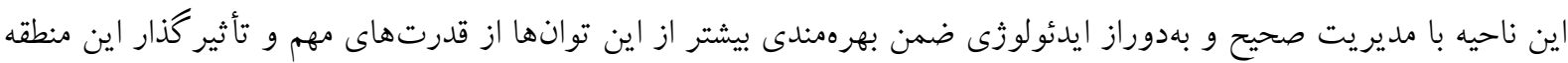

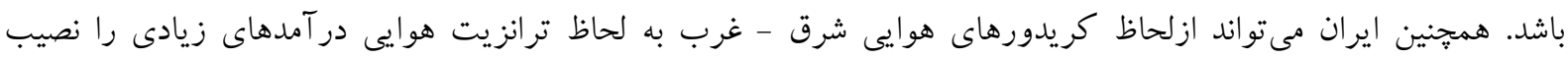



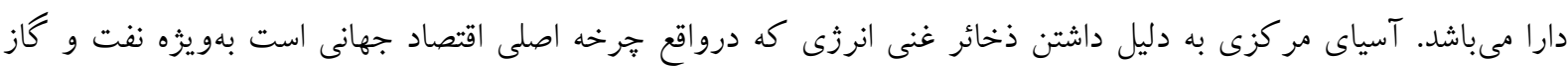

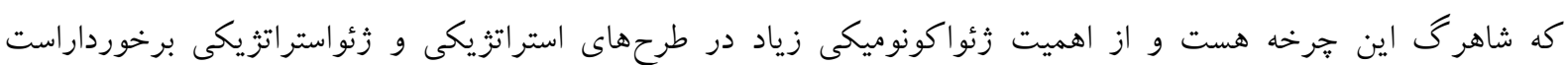

.(Ezzati, 2008)

\section{نتيجه گيرى}

تحولات دهههاى اخير در كفتمان زئواستراتزى و گرايشهاى جهانى به سمت گفتمان زئواكونومى، عملاً منجر به ايفاى

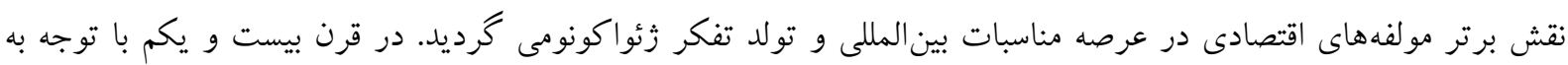


رشد جمعيت و نيازهاى گسترده جهان بشرى و نيز علىرغم تلاشهاى ويزهاى كه واحدهاى سياسى بر تأمين امنيت غذايى

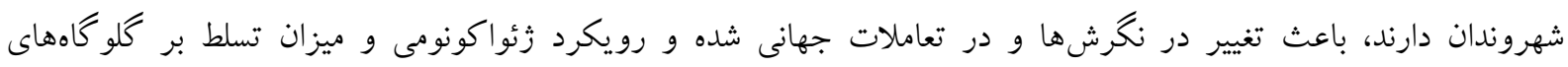

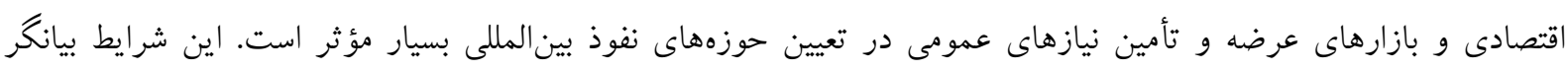

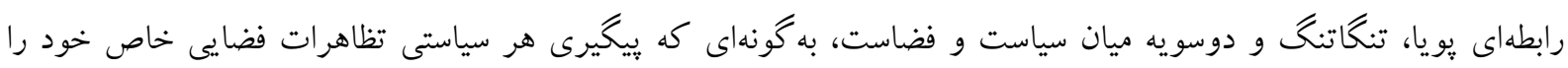

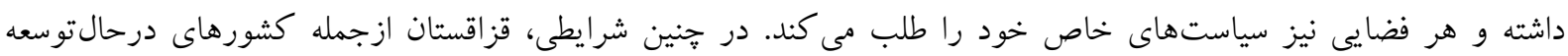

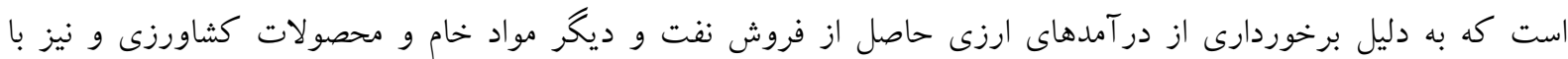

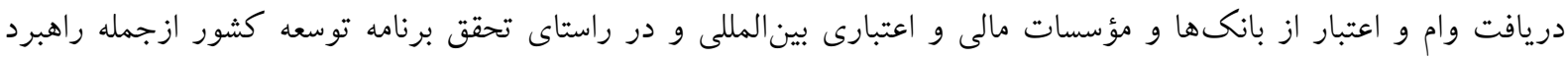

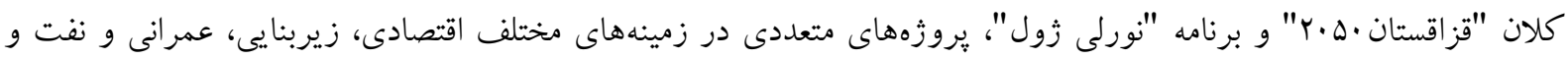

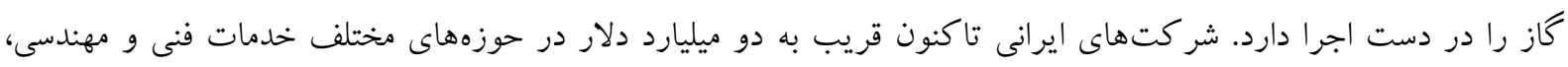

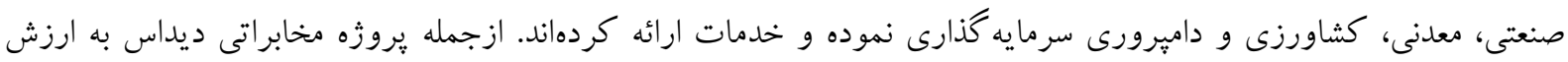

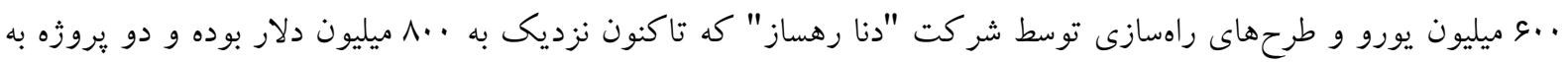

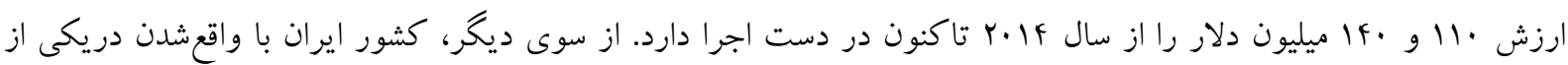

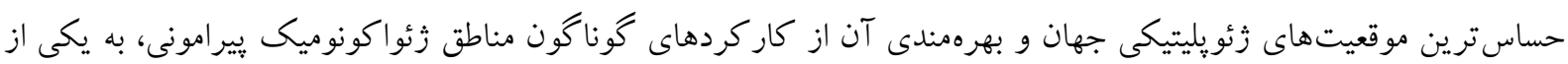

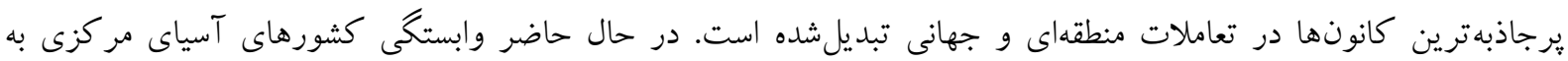

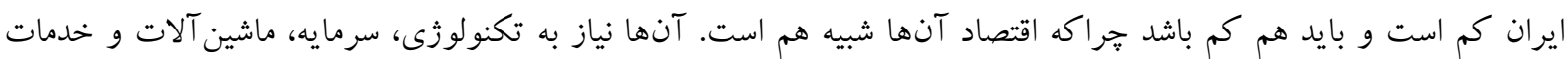

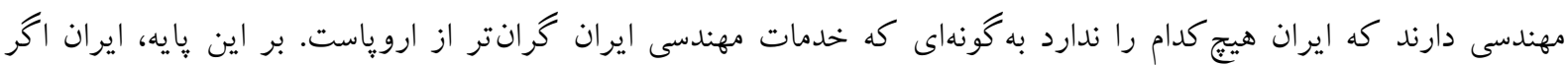

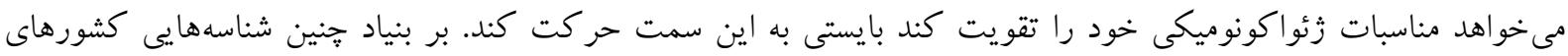

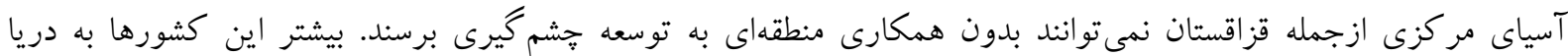

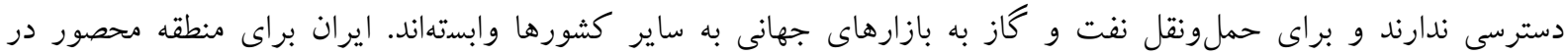

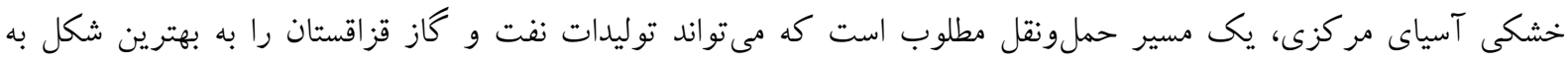

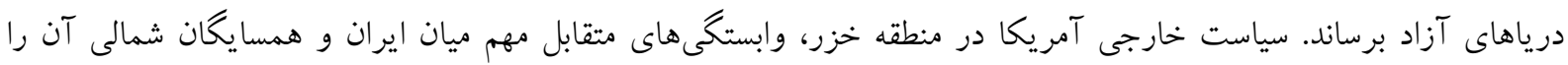

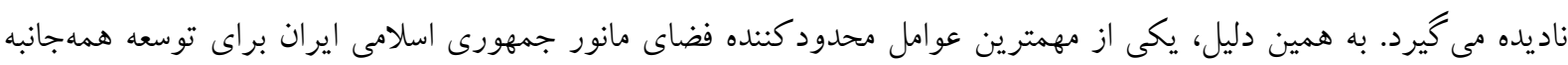

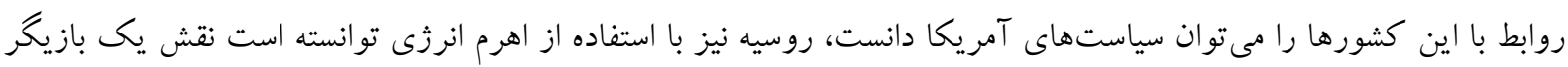

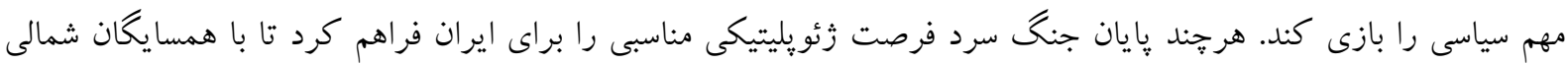

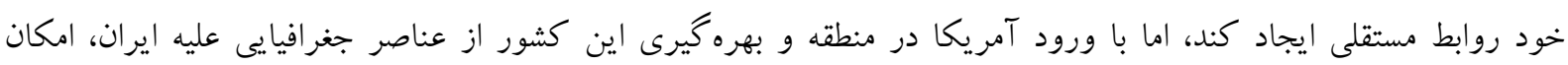

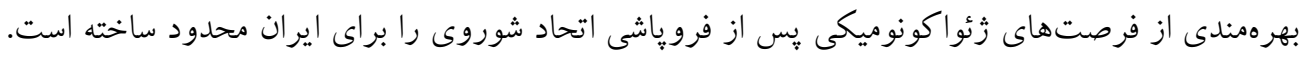

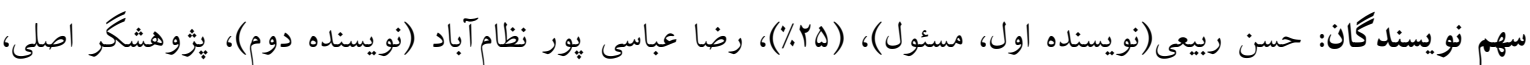

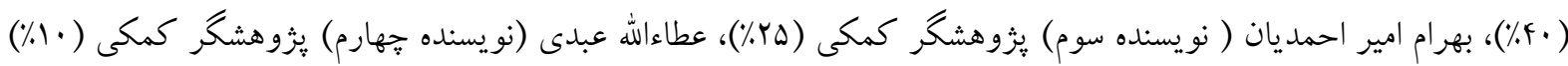

Ahmadi Lafouraki, B., \& Mirrazavi, F. (2004). Directory of Caspian region and Central Asian and Southern Caucasus countries. Tehran: Abrar Moaser. (Persian)

Akbarian, R. (2003). Investigating Iran's geopolitical situation in the field of oil and gas economics. Economic Research, 3(3-4), 109-130. (Persian)

Amirahmadian, B. (a2018). The Initiative of one road, one belt (Abrisham road \& the place of Iran), Lecture in the Iranian association of geopolitics. (Persian)

Amirahmadian, B. (b2018). The Challenges of Iran Presence in Central Asia. Fellow-citizen. (Persian) 


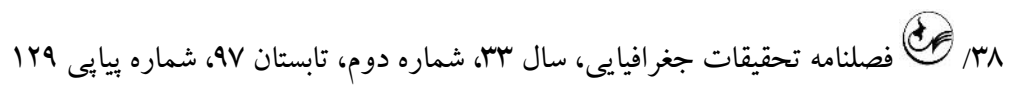

Baru, S. (2012). Geo-economics and strategy. Survival, 54(3), 47-58. [DOI:10.1080/00396338.2012.690978]

Blackwill, R. D., \& Harris, J. M. (2016). War by other means: Geoeconomics and statecraft. Cambridge: Harvard University Press. [DOI:10.4159/9780674545960]

Caucasuss Studies Institute. (2011). Central Asia and the Caucasus, the neglected arenas in Iran's foreign policy. Retrieved from http://www.ccsi.ir/vdcicqaz2t1av.bct.html. (Persian)

Dadandish, P. (2007). Geopolitical discourse in Central Asia: Opportunities for Iran-Russia cooperation. Geopolitics Quarterly, 3(1), 75-96. (Persian)

Economic Site of the Ministry of Foreign Affairs. (2018). Public information of Kazakhstan. Retrieved from http://www.mfa.gov.ir/index.aspx?fkeyid=\&siteid=464\&pageid=35783. (Persian)

Efegil, E., \& Stone, L. A. (2001). Iran's interests in Central Asia: A contemporary assessment. Central Asian Survey, 20(3), 353-365 .[DOI:10.1080/02634930120095358]

EIA. (2016). Iran energy data, statistics and analysis - oil, gas, electricity, and coal. Retrieved from http://www.eia.doe.gov/emeu/cabs/Iran/pdf.pdf

EIA. (2017). Kazakhstan energy data, statistics and analysis -oil, gas, electricity, and coal. Retrieved from http://www.eia.doe.gov/emeu/cabs/Kazakhstan/pdf.pdf

Etaat, J., \& Nosrati, H. R. (2009). Iran and energy transit routes of the Caspian basin. Central Eurasia Studies, 2(3), 1-22. (Persian)

Ezzati, E. (2001). Geopolitics in the twenty-first century. Tehran: Samt. (Persian)

Ezzati, E. (2008). The geo-economy of energy and its security impacts on Iran, Pakistan and India. Foreign Policy, 23(1), 105-114. (Persian)

Fao. (2015). Country indicators, Kazakhstan. Retrieved from http://www.fao.org/faostat/en/\#country/108

Fars News Agency. (2011). Larijani meeting with Amriyah: Iran and Kazakhstan have a lot of capacities to develop cooperation. Retrieved from http://www.farsnews.com/newstext.php?nn=13900802001215. (Persian)

Golshani, S. A., \& Sohrabi, H. R. (2012). The role of Iran's geopolitics in global energy security based on the strategic management model "swot". Political and International Research, 4(13), 163-204. (Persaian)

Hafez Nia, M. R. (2006). Geopolitical principles and concepts. Mashhad: Papoli Publications Affiliated to Amir Kabir. (Persian)

Hashemi, A. A. (2004). Political history of the soviet union, (First ed. Vol. 2). Tehran: Aftab Publishing. (Persian)

http://import-export.ir/14/Kazakhstan.html .

Johnston, R. J., Teilor, P. J., \& Wats, M. (2004). Global geography (N. Nourian, Trans.). Tehran: Extensive War Publishing. (Persian)

Kaiser, M. J., \& Pulsipher, A. G. (2007). A review of the oil and gas sector in Kazakhstan. Energy Policy, 35(2), 1300-1314 . [DOI:10.1016/j.enpol.2006.03.020]

Kamp, J., \& Harcavi, R. (2007). Strategic geography Middle East (S. M. Hoseini Matin, Trans.). Tehran: Research Institute of Strategic Studies. (Persian)

Karami, J., \& Azizi, H. R. (2013). China's security relations with Central Asia: From decurity ties to "regional security complexes". Central Eurasia Studies, 6(12), 135-154. (Persian)

Kasenov, O., \& Sanjabi, A. (1996). Kazakhstan's foreign policy priorities. Central Asian and the Caucasus Journal, 4(2), 139-160. (Persian)

Kennedy, P. (1989). The rise and fall of the great powers: Economic change and military conflict from 1500 to 200. New York: Random House.

Koolaee, E .(1997) .Politics and government in Central Asia. Tehran: Samt. (Persian)

Koolaee, E. (2009). New great game in Central Asia (background and perspectives). Tehran: Institute for Political and International Studies (Persian)

Koolaee, E., \& Ebrahimi, A. (2012). Explanation of the Islamic Republic of Iran's geopolitical relationship with Kazakhstan. Geopolitical Quarterly, 9(30), 49-81. (Persian)

Koolaee, E., \& Moaddab, M. (2009). Iran's role and importance in the energy market of the ECO region. Quarterly Foreign Relations, 1(3), 33-54. (Persian)

Koushki, M., \& Hosseini, S. M. (2017). Prospect of Islanic Republic of Iran's membership in the Shanghai cooperation organization: Opprtunties and challenges. Political Quarterly, 47(3), 737-752. (Persian)

Lotfian, S. (2011). Kazakhstan: Political developments, foreign and security policies. Tehran: University of Tehran Press. (Persian)

Luttwak, E. N. (1990). From geopolitics to geo-economics: Logic of conflict, grammar of commerce. The National Interest, 20, 17-23.

Marat, N. (2008). The republic of Kazakhstan and the economic cooperation Organization: Present state and future cooperation. Central Asia and the Caucasus, 1(49), 98-99. 
Martin, M. A. P., \& Miguel, Á. (2010). Geo-economics in Central Asia and the great game of natural resources: Water, oil, gas, uranium and transportation corridors. Central Asia Observatory, Working Paper, 59(2009), 19 .

Ministry of Foreign Affairs. (2008). Kazakhstan. Tehran: Institute for Political and International Studies . (Persian)

Mirhosseini, A. (2010). Introduction to Kazakhstan,. Journal of Geographical Studies, 1(3), 55-56. (Persian)

Mohammadi, M., \& Motaghi, A. (2006). Doctrine on constructive engagement in foreign policy of the country. Yas Strategic Quarterly, 139-190. (Persian)

Mottaghi, E., \& Hemmatkhah, M. (2008). The position of Iran in energy market of Central Asia. Journal of Central Eurasia Studies, 1(1), 127-147. (Persian)

Nasiri, H. (2008). Global-regional exchanges: An examination of Iran and its competitors position(with emphasis on eastern axis). Political Quarterly, 38(3), 349-377. (Persain )

Oliker, O. (2007). Kazakhstan's security interests and their implications for the U. S. -Kazakh relationship. China and Eurasia Forum Quarterly, 5(2), 63-72.

Paramonov, V., \& Strokov, A. (2007). Structural interdependence of Russia \& Central Asia in the oil and gas sectors. United Kingdom: Defence Academy of the United Kingdom, Conflict Studies Research Centre.

Peachey, R. (2011). Petroleum investment contracts after the Baku-Tbilisi-Ceyhan (BTC) pipeline. Northwestern Journal of International Law \& Business, 31(3), 739 .

Pishgahi Fard, Z., \& Joneidi, R. (2010). The nature of Russia's political behavior in the Central Asia region and the challenges for the Islamic Republic of Iran. Human Geography Research Quarterly, 42(2), 63-82. (Persian)

Ramazani, R. (2009). Understanding Iran's foreign policy. Quarterly Foreign Relations, 1, 11-20. (Persian)

Rasa News Agency. (2014). Retrieved from http://www.rasanews.ir/newstextsubservice/1393. (Persian)

Sarie'olghalam, M. (2017). International system and modern geo-politics in Middle East. Iranian Political Science Association, 12(1), 101-140. (Persian)

Shahbi, S., \& Sheikholeslami, M. H. (2011). Echo and Development of Iran. Quarterly of Foreign Relations, 2(4), 45-73. (Persian)

Shouri, M. (2016, 2016-7-17) Promoting Iran-Russia relations in the eleventh government of emergencycollaborative-based co-operation/Interviewer: Institute for Iranian Studiesand Eurasia. (Persian)

Solberg Søilen, K.(2012) .Geoeconomics. London: Ventus Publishing ApS/Bookboon.

Tehran Chamberog Commerce Industries Miniesand Agriculture. (2015). Basic information of Kazakhstan. Retrieved from http://www.tccim.ir/countries.aspx. (Persain)

The World Factbook. (2016). Retrieved from https://www.cia.gov/library/Pub./the-worldfactbook/LastSeen:7/7/2017

Trade Promotion Organization of Iran. (2015). Report on trade between Iran and Kazakhstan in 2014. Retrieved from http://farsi.tpo.ir/uploads/iran-ghazaghestan93_10156.pdf. (Persian)

Valigholizadeh, A. (2015). Spatial-geoeconomic analysis and analysis of Iran's business relationships with the CIA field. Central Eurasian Studies, 8(2), 343-364. (Persian)

Yuldasheva, G. (2008). Geopolitics of Central Asia in the context of the Iranian factor. Caucasian review of international affairs (CRIA), 2(3), 133-145.

Zabortsevas, Y. N. (2010). Kazakhstan's bilateral economic relations with Russia: a robust partnership?. BASEES 2010 Annual Conference .

Zardykhan, Z. (2002). Kazakhstan and Central Asia: regional perspectives. Central Asian Survey, 21(2), 167183 . [DOI:10.1080/0263493022000010062] 